\title{
Effects of abomasal infusion of essential fatty acids and conjugated linoleic acid on performance and fatty acid, antioxidative, and inflammatory status in dairy cows
}

\author{
S. Haubold, ${ }^{1}$ C. Kröger-Koch, ${ }^{1}$ A. Starke, ${ }^{2}$ A. Tuchscherer, ${ }^{1}$ A. Tröscher, ${ }^{3} \odot$ H. Kienberger, ${ }^{4}$ M. Rychlik, ${ }^{5}$ \\ U. Bernabucci, ${ }^{6} \odot$ E. Trevisi, ${ }^{7}{ }^{\circ}$ and H. M. Hammon ${ }^{1 *}{ }^{1}$ \\ ${ }^{1}$ Leibniz Institute for Farm Animal Biology (FBN), 18196 Dummerstorf, Germany \\ ${ }^{2}$ Clinic for Ruminants and Swine, Faculty of Veterinary Medicine, University of Leipzig, 04103 Leipzig, Germany \\ ${ }^{3}$ BASF SE, 68623 Lampertheim, Germany \\ ${ }^{4}$ Bavarian Center for Biomolecular Mass Spectrometry, Technische Universität München, 85354 Freising, Germany \\ ${ }^{5}$ Chair of Analytical Food Chemistry, Technical University of Munich, 85354 Freising, Germany \\ ${ }^{6}$ Dipartimento di Scienze Agrarie e Forestali, Università degli Studi della Tuscia, 01100 Viterbo, Italy \\ ${ }^{7}$ Department of Animal Sciences, Food and Nutrition (DIANA), Università Cattolica del Sacro Cuore, 29122 Piacenza, Italy
}

\section{ABSTRACT}

The objective of this study was to test the effects of essential fatty acids (EFA), particularly $\alpha$-linolenic acid, and conjugated linoleic acid (CLA) supplementation on fatty acid (FA) composition, performance, and systemic and hepatic antioxidative and inflammatory responses in dairy cows. Four cows $(126 \pm 4 \mathrm{~d}$ in milk) were investigated in a $4 \times 4$ Latin square and were abomasally infused with 1 of the following for $6 \mathrm{wk}$ : (1) coconut oil (control treatment, CTRL; $38.3 \mathrm{~g} / \mathrm{d}$; providing saturated FA), (2) linseed and safflower oil (EFA treatment; 39.1 and $1.6 \mathrm{~g} / \mathrm{d}$, respectively; providing mainly $\alpha$-linolenic acid), (3) Lutalin (BASF, Ludwigshafen, Germany; CLA treatment; cis-9,trans-11 and trans-10, cis-12 CLA, $4.6 \mathrm{~g} / \mathrm{d}$ each), (4) or EFA+CLA. The initial dosage was doubled every $2 \mathrm{wk}$, resulting in 3 dosages (dosage 1, 2, and 3 ). Cows were fed a corn silage-based total mixed ration with a high n-6/n-3 FA ratio. Dry matter intake and milk yield were recorded daily, and milk composition was measured weekly. The FA compositions of milk fat and blood plasma were analyzed at wk $0,2,4$, and 6 . The plasma concentration and hepatic mRNA abundance of parameters linked to the antioxidative and inflammatory response were analyzed at wk 0 and 6 of each treatment period. Infused FA increased in blood plasma and milk of the respective treatment groups in a dose-dependent manner. The n-6/n-3 FA ratio in milk fat was higher in CTRL and CLA than in EFA and EFA+CLA. The sum of FA

Received June 21, 2019

Accepted September 23, 2019.

*Corresponding author: hammon@fbn-dummerstorf.de
$<$ C16 in milk fat decreased in CLA and EFA+CLA in a dosage-dependent manner. Energy-corrected milk and milk fat decreased in CLA and EFA+CLA in a dosage-dependent manner and were higher in EFA and CTRL than in CLA at dosages 2 and 3. Energy balance tended to be highest in CLA cows. Milk protein content was lower in CLA and EFA+CLA than in CTRL. Milk urea concentration decreased in CLA and EFA+CLA in a dosage-dependent manner and was lower in CLA and EFA+CLA than in EFA and CTRL at dosages 2 and 3. Milk citrate concentration increased in CLA in a dosage-dependent manner and was higher in CLA and EFA+CLA than in EFA and CTRL. Glutathione peroxidase activity in blood plasma was lower in CTRL than in EFA, and plasma concentration of $\beta$-carotene increased in EFA and EFA+CLA with dosage. Increased milk citrate pointed at reduced de novo FA synthesis and a better antioxidative status in milk due to CLA treatment. Supplementation with CLA may also affect milk protein synthesis, but EFA and CLA treatment did not influence the inflammatory status in a consistent manner in mid-lactating cows.

Key words: dairy cow, essential fatty acid, conjugated linoleic acid, inflammatory status

\section{INTRODUCTION}

The importance of essential fatty acids (EFA) namely, $\alpha$-linolenic acid (ALA) and linoleic acid (LA) - to the functionality of the organism in mammalian species is well known (Simopoulos, 2002; Lands, 2014). In addition to their cell membrane function, ALA with its metabolites eicosapentaenoic acid (EPA), docosapentaenoic acid (DPA), and docosahexaenoic acid (DHA) and LA with its main metabolite arachidonic 
acid (ARA) serve as precursors for prostaglandin synthesis and mediate reproductive functions and the acute phase response (Mattos et al., 2000; Wathes et al., 2007; Sordillo et al., 2009). $\alpha$-Linolenic acid and LA cannot be synthesized by mammals and must be obtained from food (Spector and Kim, 2015), which is also applicable to ruminants (Palmquist, 2010). Furthermore, ruminal synthesis of CLA isomers depends on LA and ALA intake (Bauman et al., 2000; Chilliard et al., 2001; Shingfield et al., 2010). Some CLA isomers have health-promoting effects in mammals (Nagao and Yanagita, 2005; Shokryzadan et al., 2017) but also reveal metabolic effects in dairy cows (e.g., milk fat-reducing and glucose-saving effects; Bauman et al., 2000, 2011; Hötger et al., 2013).

Over the last few decades, diets for dairy cows have changed, with less pasture but more TMR based on corn silage as the main forage source provided. Therefore, fatty acid (FA) supply and the intake of EFA have also changed. Grass in pastures contains high levels of ALA (Chilliard et al., 2001; Khiaosa-Ard et al., 2015), and rumen digestion of PUFA produces significant amounts of CLA when cows are on pasture (Kelly et al., 1998; Ferlay et al., 2006). The importance of n-3 FA in dairy production has already been reviewed (Palmquist, 2010; Moallem, 2018). In contrast, corn silage is rich in LA, but rations commonly contain less fat, and low levels of CLA are available to cows (Chilliard et al., 2001; Khan et al., 2015). Therefore, the forage type strongly affects the EFA and n-6/n-3 FA ratio as well as the CLA status of dairy cows (Chilliard et al., 2001; Shingfield et al., 2010; Khan et al., 2015).

Changes in EFA supply may have an important effect on metabolic regulation (Pegolo et al., 2016) and functional immunity in ruminants (Sordillo et al., 2009; Rezamand et al., 2016; Sordillo, 2016), as is known from human studies (Calder, 2013; Lands, 2014; Simopoulos and DiNicolantonio, 2016). Altering the n-6/n-3 FA ratio in diets influences the lactation performance and inflammatory response in dairy cows (Silvestre et al., 2011; Trevisi et al., 2011; Greco et al., 2015) and bovine cell culture models (Contreras et al., 2012; Dipasquale et al., 2018). Furthermore, in addition to the metabolic effects, CLA supplementation can influence the inflammatory response (Yu et al., 2002; Viladomiu et al., 2016), and studies in dairy cows seem to support an antioxidative effect of CLA (Hanschke et al., 2016). High milk production is associated with oxidative stress, in particular during early lactation (Sordillo et al., 2009; Hanschke et al., 2016), and the effect of EFA supplementation on oxidative stress and antioxidative capacity in cows needs to be clarified. Furthermore, less is known about whether a combined EFA and CLA treatment has synergistic or opposing effects on the inflammatory response and oxidative status in dairy cows.

The aim of the present study was to investigate the immediate effects of increasing EFA and CLA dosages on lactation performance and immunological changes in dairy cows during established lactation. The treatments focused on the supply of FA that provide a reduced n6/n-3 EFA ratio, in particular an increase in ALA supply, and CLA. Such a dietary FA composition usually occurs in cows fed fresh grass or cows that are on pasture (Kelly et al., 1998; Ferlay et al., 2006). Cows were supplied ALA (from linseed oil), CLA (cis-9,trans-11 and trans-10,cis-12 CLA in equal amounts), or a combination of both in increasing amounts and comparable with a pasture-based feeding system (Kelly et al., 1998; Ferlay et al., 2006). To avoid rumen degradation of the supplemented FA, all FA were infused as oils into the abomasum. We hypothesized that an elevated ALA and CLA intake would immediately change the EFA and CLA status and affect lactation performance, milk synthesis, and immunological and oxidative statuses during mid-lactation in dairy cows.

\section{MATERIALS AND METHODS}

\section{Animal Husbandry, Feeding, and FA Supplementation}

The experimental procedures in the current study were performed in strict accordance with the German Animal Welfare Act and were approved by the relevant Department for Animal Welfare Affairs of the state of Mecklenburg-West Pomerania (Landesamt für Landwirtschaft, Lebensmittelsicherheit und Fischerei Mecklenburg-Vorpommern, Germany; LALLF M-V/ TSD/7227.3-1-061/14).

Four German Holstein cows $(>10,000 \mathrm{~kg}$ of milk in $305 \mathrm{~d}$ in second lactation; $126 \pm 4$ DIM at start of the study) with an average BW of $578 \pm 13.9 \mathrm{~kg}$ were purchased from a local farm (Adap Rinderzucht GmbH, Ahrenshagen, Germany) 3 mo before starting the trial and kept in the freestall barn of the experimental cattle facility at the Leibniz Institute for Farm Animal Biology (FBN, Dummerstorf, Germany). Cows were immediately adapted to the experimental diet. The diet contained only corn silage and straw as forage sources and other components that delivered a low fat content and high n-6/n-3 FA ratio (Tables 1 and 2; Supplemental Table S1; https://doi.org/10.3168/jds.2019-17135). The diet was offered ad libitum. The chemical composition of the diet was calculated in accordance with the recommendations of the German Society of Nutritional 
Physiology (GfE, 2001, 2008). The cows always had free access to water. Cows were surgically implanted with rumen cannulas $8 \mathrm{wk}$ before the start of the study (10-cm center diameter cannula; Bar Diamond Inc., Parma, ID). An abomasal infusion line (polytetrafluoroethylene tube; 6-mm i.d., 8-mm o.d.), fixed at the rumen cannula cap and passing the sulcus omasi, was placed into the abomasum as previously described by Spires et al. (1975) immediately before the start of the study. Two perforated polytetrafluoroethylene flanges (1- and 1.5-mm thickness, $118-\mathrm{mm}$ diameter with 5 holes, circularly arranged, 16-mm diameter) were fixed at the end of the tube, preventing its retraction from the abomasum. Patency and placement of the tubes within the abomasum were checked manually every day.

Cows were arranged in a $4 \times 4$ Latin square design with 4 treatments. Cows in the control (CTRL) treatment received coconut oil (Sanct Bernhard, Bad Ditzenbach, Germany), which comprised predominantly SFA. Cows in the EFA treatment received a mix of linseed oil (Derby, Derby Spezialfutter GmbH, Münster, Germany) and safflower oil (Gefro, GC Memmingen/

Table 1. Ingredients and chemical composition of the experimental diet $(\mathrm{g} / \mathrm{kg}$ of DM unless otherwise noted)

\begin{tabular}{|c|c|}
\hline Item & Value \\
\hline \multicolumn{2}{|l|}{ Ingredient, $\mathrm{g} / \mathrm{kg}$ of $\mathrm{DM}$} \\
\hline Corn silage & 433 \\
\hline Straw & 115 \\
\hline Extracted soybean meal $^{1}$ & 124 \\
\hline Dried sugar beet pulp ${ }^{1}$ & 207 \\
\hline Grain of rye ${ }^{1}$ & 101 \\
\hline Minerals $^{2}$ & 10 \\
\hline Chalk $^{3}$ & 2 \\
\hline Salt $^{3}$ & 2 \\
\hline Urea $^{4}$ & 7 \\
\hline \multicolumn{2}{|l|}{ Chemical composition } \\
\hline Crude fat & 24 \\
\hline Crude fiber & 179 \\
\hline $\mathrm{CP}$ & 149 \\
\hline Utilizable protein ${ }^{5}$ & 147 \\
\hline Starch & 225 \\
\hline $\mathrm{ADF}$ & 204 \\
\hline NDF & 361 \\
\hline $\mathrm{NE}_{\mathrm{L}},{ }^{5} \mathrm{MJ} / \mathrm{kg}$ of $\mathrm{DM}$ & 6.7 \\
\hline
\end{tabular}

${ }^{1}$ Fugema/Ceravis AG (Malchin, Germany).

${ }^{2}$ Rinderstolz 9522 (Salvana GmbH, Sparrieshoop, Germany) comprised the following: $92 \%$ crude ash, $20 \%$ calcium, $5 \%$ phosphorus, $6 \%$ magnesium, $8 \%$ sodium, 1,000,000 IU $/ \mathrm{kg}$ vitamin $\mathrm{A}, 200,000 \mathrm{IU} / \mathrm{kg}$ vitamin $\mathrm{D}_{3}, 4.5 \mathrm{mg} / \mathrm{kg}$ vitamin $\mathrm{E}$ ( $\alpha$-tocopherol acetate), $1.5 \mathrm{mg} / \mathrm{kg}$ copper sulfate, $8.0 \mathrm{mg} / \mathrm{kg}$ zinc oxide, $5.0 \mathrm{mg} / \mathrm{kg}$ manganese oxide, 60 $\mathrm{mg} / \mathrm{kg}$ calcium iodate, and $50 \mathrm{mg} / \mathrm{kg}$ sodium selenite.

${ }^{3} \mathrm{Chalk}=\mathrm{CaCO}_{3} ;$ salt $=\mathrm{NaCl}$ (Spezialfutter Neuruppin $\mathrm{GmbH} \& \mathrm{Co}$. KG, Neuruppin, Germany).

${ }^{4} \mathrm{CH}_{4} \mathrm{~N}_{2} \mathrm{O}$ (Bergophor Futtermittelfabrik Dr. Berger GmbH \& Co. KG, Kulmbach, Germany).

${ }^{5} \mathrm{GfE}$ (2008).
Allgäu, Germany) to provide an n-6/n-3 FA ratio of 1:3. Cows in the CLA treatment received Lutalin (BASF, Ludwigshafen, Germany), providing cis-9,trans-11 CLA and trans-10,cis-12 CLA. Finally, cows in the EFA+CLA treatment received a combination of EFA and CLA. The amounts of the infused oils are shown in Table 3. Each supplementation period lasted for $6 \mathrm{wk}$ in total; during this time, cows received lipid supplementation in 3 successively increasing dosages each for $2 \mathrm{wk}$, resulting in 3 dosages of each treatment (dosage 1,2 , and 3 ). Subsequent to the supplementation period, a 3-wk washout period (no supplementation) followed for transition before the treatment changed. The basal doses of FA applications were based on previous studies (Benson et al., 2001; Pires et al., 2008; Hötger et al., 2013) and considered changes in n-3 and n-6 FA in cows due to pasture feeding (Ferlay et al., 2006; Khiaosa-Ard et al., 2015). The daily amount of the infused supplements was split into 2 equal portions and abomasally infused after the milking process at 0700 and $1600 \mathrm{~h}$.

\section{Performance Data and Analyses of Diet, Fat Supplements, and Milk}

Individual feed intake was recorded daily using troughs connected to an electronic scale to which access was controlled by individual transponders (Roughage Intake Control, Insentec, Marknesse, the Netherlands). Feed samples of TMR and corn silage were taken weekly, and DM content from TMR was determined weekly. Samples of single components, such as barley straw, dried beet pulp, rye grains, and soy extraction meal, were pooled every 2 mo. Samples for determination of nutrient composition and FA profile were initially stored at $-20^{\circ} \mathrm{C}$. Samples were dried and ground before analysis. Samples of the oil supplements were taken from each charge for Weender analyses and analysis of FA composition. The chemical composition of the samples was determined according to the Weender standard procedure (Naumann and Bassler, 2012) at the Agricultural Analysis and Research Institute (LUFA, Rostock, Germany). Net energy for lactation was $19.3 \mathrm{MJ} / \mathrm{kg}$ of $\mathrm{DM}$ for coconut oil, linseed oil, and safflower oil and 21.6 MJ/kg of DM for Lutalin. Fat extraction was performed using petroleum ether following the protocol of Naumann and Bassler (2012), and then FA were determined by GC (Hewlett Packard 6890 GC, Agilent Technologies, Boeblingen, Germany) according to methods of the German Society for Fat Science (2015). The FA compositions of the diet, the native oils, and the supplements are presented in Table 2 and Supplemental Tables S1 and S2 (https://doi.org/ 10.3168/jds.2019-17135). 
Body weight was measured once a week after morning milking before feeding. Back fat thickness (BFT) was measured weekly via ultrasound (Titan Ultrasound System, SonoSite Inc., Bothell, WA) according to Schröder and Staufenbiel (2006), and BCS was determined using a 5-point scale as described by Edmonson et al. (1989). Energy balance (EB) was calculated as follows (Reist et al., 2003): $\mathrm{EB}=\mathrm{NE}_{\mathrm{L}}$ intake $-(\mathrm{ECM}$ $\times 3.14+0.293 \times \mathrm{kg}$ of $\left.\mathrm{BW}^{0.75}\right)$. Energy intake includes the energy from the diet and FA supplements.

Cows were milked twice daily at 0700 and 1600 h. Milk yield was recorded electronically after each milking. Milk samples were taken weekly from a milking one afternoon and the successive morning. Milk samples were pooled for the determination of protein, fat, lactose, and urea concentrations using an infrared spectrophotometric method (MilkoScan FT6000/FT+,
Foss GmbH, Hamburg, Germany) at Landeskontrollverband für Leistungs- und Qualitätsprüfung Mecklenburg-Vorpommern e.V. (Güstrow, Germany). In milk samples collected after each 2-wk lipid supplementation period, individually, and after the 3 -wk washout period, FA were determined by lipid extraction and GC with flame ionization detection as previously described (Firl et al., 2014). At the same time points, milk citrate was measured using a commercial enzymatic kit (no. 10139076035) from R-Biopharm AG (Darmstadt, Germany) at the Institut für Analytik und Hygiene (MQD, Güstrow, Germany). Milk acetone was determined at the same institute by the Skalar method using a continuous flow analyzer $(\mathrm{SAN}++$, Skalar Analytic $\mathrm{GmbH}$, Erkelenz, Germany), following the procedure described by de Roos et al. (2007). To calculate the ECM yield, the following formula was used: ECM $(\mathrm{kg})=(0.038 \times \mathrm{g}$

Table 2. Fatty acid (FA) composition of the diet and infused fat supplements ${ }^{1}$

\begin{tabular}{|c|c|c|c|c|c|}
\hline $\mathrm{FA}, \%$ & Diet & CTRL & EFA & CLA & $\mathrm{EFA}+\mathrm{CLA}$ \\
\hline 6:0 & 0.00 & 0.67 & 0.00 & 0.00 & 0.00 \\
\hline 8:0 & 0.00 & 8.49 & 0.00 & 0.00 & 0.00 \\
\hline 10:0 & 0.00 & 6.58 & 0.00 & 0.00 & 0.00 \\
\hline 12:0 & 0.09 & 48.87 & 0.00 & 0.00 & 0.00 \\
\hline 14:0 & 0.63 & 17.63 & 0.02 & 0.00 & 0.02 \\
\hline 15:0 & 0.18 & 0.00 & 0.00 & 0.08 & 0.02 \\
\hline 16:0 & 21.86 & 7.74 & 5.59 & 5.50 & 5.58 \\
\hline $16: 1$ cis -9 & 0.22 & 0.00 & 0.06 & 0.07 & 0.06 \\
\hline $17: 0$ & 0.27 & 0.00 & 0.05 & 0.07 & 0.05 \\
\hline 18:0 & 3.17 & 2.84 & 3.31 & 4.33 & 3.61 \\
\hline $18: 1$ cis-9 & 20.29 & 4.83 & 20.32 & 26.22 & 22.06 \\
\hline 18:1 cis-11 & 0.98 & 0.00 & 0.56 & 0.67 & 0.59 \\
\hline $18: 2$ cis- 9, cis- 12 & 44.21 & 0.89 & 17.36 & 2.61 & 13.20 \\
\hline $18: 2$ cis- 9, trans -11 & 0.00 & 0.00 & 0.00 & 28.91 & 8.24 \\
\hline 18:2 cis-9,trans-12 & 0.00 & 0.00 & 0.02 & 0.00 & 0.01 \\
\hline $18: 2$ trans -10, cis -12 & 0.00 & 0.00 & 0.00 & 28.90 & 8.24 \\
\hline $18: 3$ cis- 9, cis- 12, cis -15 & 3.93 & 0.00 & 52.27 & 0.00 & 37.52 \\
\hline 20:0 & 0.72 & 0.06 & 0.13 & 0.25 & 0.17 \\
\hline 20:1 cis- 11 & 0.45 & 0.00 & 0.12 & 0.54 & 0.24 \\
\hline $22: 0$ & 1.16 & 0.00 & 0.11 & 0.68 & 0.27 \\
\hline 23:0 & 0.00 & 0.34 & 0.00 & 0.00 & 0.00 \\
\hline 24:0 & 1.43 & 0.07 & 0.07 & 0.17 & 0.10 \\
\hline $24: 1$ cis- 15 & 0.00 & 0.00 & 0.00 & 0.00 & 0.00 \\
\hline $\mathrm{SFA}^{2}$ & 29.51 & 93.28 & 9.30 & 11.08 & 9.84 \\
\hline MUFA $^{3}$ & 21.94 & 4.83 & 21.07 & 27.50 & 22.96 \\
\hline PUFA $^{4}$ & 48.14 & 0.89 & 69.63 & 2.61 & 50.72 \\
\hline Total CLA ${ }^{5}$ & 0.00 & $<0.05$ & 0.00 & 57.80 & 16.48 \\
\hline Total trans FA & 0.00 & $<0.05$ & $<0.05$ & $<0.05$ & $<0.05$ \\
\hline Sum of $n-3 F^{6}$ & 3.93 & $<0.05$ & 52.27 & $<0.05$ & 37.52 \\
\hline Sum of $n-6 \mathrm{FA}^{7}$ & 44.21 & 0.89 & 17.36 & 2.61 & 13.20 \\
\hline
\end{tabular}

${ }^{1}$ CTRL $($ control) $=$ coconut oil (Bio-Kokosöl no. 665, Kräuterhaus Sanct Bernhard KG, Bad Ditzenbach, Germany). EFA = linseed (Derby Leinöl no. 4026921003087, Derby Spezialfutter GmbH, Münster, Germany) and safflower oil (Gefro Distelöl, Gefro Reformversand Frommlet KG, Memmingen, Germany). CLA = Lutalin (CLA cis-9,trans-11 and trans-10, cis-12, BASF SE, Ludwigshafen, Germany). EFA+CLA = linseed (Derby Leinöl no. 4026921003087), safflower oil (Gefro Distelöl), and Lutalin.

${ }^{2}$ Consisted of 6:0, 8:0, 10:0, 12:0, 14:0, 15:0, 16:0, 17:0, 18:0, 20:0, 22:0, 23:0, and 24:0.

${ }^{3}$ Consisted of $16: 1$ cis- $9,18: 1$ cis- $9,18: 1$ cis-11, 20:1 cis-11, and 24:1 cis-15.

${ }^{4}$ Consisted of $18: 2$ cis-9, cis-12 and 18:3 cis-9,cis-12,cis-15.

${ }^{5}$ Consisted of 18:2 cis-9,trans-11 and 18:2 trans-10,cis-12.

${ }^{6}$ Consisted of $18: 3$ cis- 9 , cis- 12, cis- 15 .

${ }^{7}$ Consisted of 18:2 cis-9, cis-12. 
of crude fat $+0.024 \times \mathrm{g}$ of $\mathrm{CP}+0.017 \times \mathrm{g}$ of lactose $)$ $\times \mathrm{kg}$ of milk/3.14 (Reist et al., 2003).

\section{Blood Sampling and Analyses}

Blood samples were taken from the jugular vein after the morning milking and before feeding using a vacuum tube system (Vacuette, Greiner Bio-One International AG, Frickenhausen, Germany). Samples were collected before the start of the study, after every 2-wk dosedependent supplementation period (wk 2, 4, 6), and after each 3-wk washout period (wk 0). Blood samples were immediately placed on ice and then centrifuged at $1,500 \times g$ at $4^{\circ} \mathrm{C}$ for $20 \mathrm{~min}$. The harvested plasma was stored at $-20^{\circ} \mathrm{C}$ until analysis (at $-80^{\circ} \mathrm{C}$ for analyses of immune and antioxidative parameters). The FA composition in plasma was measured in blood samples containing potassium-EDTA $(1.8 \mathrm{~g} / \mathrm{L})$ from all time points mentioned above (wk 0, 2, 4,6) following the procedure described by Firl et al. (2013) by the use of lipid extraction and GC.

For measurements of parameters linked to antioxidative and inflammatory status, Li-heparinized plasma samples (12-30 IU of heparin/10 mL) were taken in wk 0 and 6 . The biological antioxidant potential of plasma samples was measured by colorimetric determination using a commercial kit (biological antioxidant potential test, Diacron, Groseto, Italy) based on the method described by Benzie and Strain (1996). Plasma reactive oxygen metabolites were measured by the analytical method patented by Diacron (Diacron, Groseto, Italy; Bernabucci et al., 2002). The results of the analyses were expressed in Carratelli units. The value of 1 Carratelli unit corresponds to a concentration of $0.08 \mathrm{mg} /$ $\mathrm{dL}$ of hydrogen peroxide. The malondialdehyde concentration in plasma samples was measured by using a colorimetric kit (lipid peroxidation assay kit, ab118970, Abcam, Cambridge, UK; Essid et al., 2012). Ferric reducing antioxidant power (FRAP) was analyzed at $37^{\circ} \mathrm{C}$ by an automated clinical analyzer (ILAB 650, Instrumentation Laboratory, Werfen, Bedford, MA). The FRAP was analyzed by adapting a colorimetric method (Benzie and Strain, 1996). Total antioxidants were assessed through the oxygen radical absorbance capacity assay. This method is based on the measurement of a fluorescent signal from a probe (fluorescein) that decreases in the presence of radical damage (Cao and Prior, 1999). The analysis of oxygen radical absorbance capacity was performed with a multidetection microplate reader equipped with a dual reagent injector (BioTek Synergy 2, BioTek, Winooski, VT). Plasma thiol groups were determined by titration with 5,5-dithiobis-2-nitrobenzoic acid using a commercial kit (plasma thiol group test, Diacron, Groseto, Italy; Bernabucci et al., 2005). Plasma glutathione peroxidase (GPX) activity was determined by a commercial kit (EGPX-100 EnzyChrom Glutahione Peroxidase Assay Kit, BioAssay Systems, Hayward, CA) as previously described by Bernabucci et al. (2005). The GPX activity was expressed in units per liter, whereas 1 unit is the amount of GPX that produces 1 micromole of oxidized glutathione per minute at $\mathrm{pH} 7.6$ and room temperature. Plasma vitamin $\mathrm{A}$, vitamin $\mathrm{E}$, and $\beta$-carotene were extracted with hexane and analyzed by reverse-phase

Table 3. Amounts of daily abomasally infused supplements

\begin{tabular}{|c|c|c|c|c|c|c|c|}
\hline \multirow[b]{2}{*}{ Supplementation } & \multicolumn{7}{|c|}{ Treatment ${ }^{1}$} \\
\hline & $\begin{array}{c}\mathrm{CTRL}^{2} \\
\begin{array}{c}\text { Coconut } \\
\text { oil }\end{array}\end{array}$ & $\begin{array}{l}\text { Linseed } \\
\text { oil }\end{array}$ & $\begin{array}{l}\text { Safflower } \\
\text { oil }\end{array}$ & $\begin{array}{c}\text { CLA }^{2} \\
\text { Lutalin }\end{array}$ & $\begin{array}{c}\text { Linseed } \\
\text { oil }\end{array}$ & $\begin{array}{l}\text { Safflower } \\
\text { oil }\end{array}$ & Lutalin \\
\hline \multicolumn{8}{|l|}{ Daily infused oils, ${ }^{3} \mathrm{~g} / \mathrm{d}$} \\
\hline Dosage 1 & 38.3 & 39.1 & 1.6 & 16.0 & 39.1 & 1.6 & 16.0 \\
\hline \multicolumn{8}{|l|}{ Daily infused fatty acids at dosage $1,^{3} \mathrm{~g} / \mathrm{d}$} \\
\hline $18: 3$ cis -9, cis -12, cis -15 & 0.0 & 21.1 & 0.0 & 0.0 & 21.1 & 0.0 & 0.0 \\
\hline $18: 2$ cis- 9, cis- 12 & 0.0 & 5.8 & 1.2 & 0.4 & 5.8 & 1.2 & 0.4 \\
\hline $18: 2$ cis- 9, trans- 11 & 0.0 & 0.0 & 0.0 & 4.6 & 0.0 & 0.0 & 4.6 \\
\hline $18: 2$ trans -10, cis -12 & 0.0 & 0.0 & 0.0 & 4.6 & 0.0 & 0.0 & 4.6 \\
\hline
\end{tabular}

${ }^{1}$ CTRL $($ control $)=$ coconut oil (Bio-Kokosöl no. 665, Kräuterhaus Sanct Bernhard KG, Bad Ditzenbach, Germany). EFA = linseed (Derby Leinöl no. 4026921003087, Derby Spezialfutter GmbH, Münster, Germany) and safflower oil (Gefro Distelöl, Gefro Reformversand Frommlet KG, Memmingen, Germany). CLA = Lutalin (CLA cis-9,trans-11 and trans-10, cis-12, BASF SE, Ludwigshafen, Germany). EFA + CLA $=$ linseed (Derby Leinöl no. 4026921003087), safflower oil (Gefro Distelöl), and Lutalin.

${ }^{2}$ Addition of vitamin E $(0.03,0.06$, and $0.12 \mathrm{~g} / \mathrm{d}$ for dosages 1, 2, and 3, respectively; Covitol 1360, BASF SE) to compensate for vitamin E in linseed oil (0.07\%) and safflower oil (0.035\%; see Supplemental Table S1, https://doi.org/10.3168/jds.2019-17135).

${ }^{3}$ The initial dosage 1 was doubled twice for 2 wk to dosages 2 and 3 , resulting in a 6 -wk treatment period that was followed by a 3 -wk washout period. 
HPLC using an Allsphere ODS-2 column $(3 \mu \mathrm{m}, 150 \times$ $4.6 \mathrm{~mm}$; Grace Davison Discovery Sciences, Deerfield, IL); a UV detector set at $325 \mathrm{~nm}$ (for vitamin A), 290 $\mathrm{nm}$ (for vitamin $\mathrm{E}$ ), or $460 \mathrm{~nm}$ (for $\beta$-carotene); and 80:20 methanol:tetrahydrofurane as the mobile phase (Trevisi et al., 2015).

Plasma haptoglobin and paraoxonase were analyzed at $37^{\circ} \mathrm{C}$ using an automated clinical analyzer. Haptoglobin was determined using the method proposed by Skinner et al. (1991). The activity of paraoxonase was assessed by adapting the method of Ferré et al. (2002), as previously described by Bionaz et al. (2007). Bovine IL-1 $\beta$ (no. ESS0027; Endogen, Pierce, Rockford, IL) and IL-6 (no. ESS0029; Endogen, Pierce) plasma concentrations were analyzed by a colorimetric sandwich ELISA using commercial kits (Trevisi et al., 2015). The intra- and interassay coefficients of variation were 6.0 and $15.3 \%$ for IL-1 $\beta$ and 5.7 and $11.9 \%$ for IL-6, respectively.

\section{Analyses of VFA and pH in Rumen Fluid}

Rumen fluid was taken at the start of the study, after each 6-wk treatment period, and after each washout period using a customized rumen fluid extractor passing the rumen fistula. The rumen fluid was put directly on ice and sieved afterward (mesh size: $0.7-1 \mathrm{~mm}$ ). Ruminal fluid $\mathrm{pH}$ was measured immediately after sampling using a glass electrode (Roth, Karlsruhe, Germany), followed by centrifugation of the filtrate for $10 \mathrm{~min}$ at $4,000 \times g$ at $4^{\circ} \mathrm{C}$. To measure the VFA concentrations in rumen fluid in the supernatant, a gas chromatograph (GC-FID, Series 17A, Shimadzu Corp., Kyoto, Japan) equipped with a 25-m FFAP column was used according to Ryan (1980).

\section{Liver Tissue Sampling and Analyses}

Liver samples were obtained by needle biopsy under local anesthesia immediately before starting the trial for basal sampling and after every 6 -wk supplementation period. Liver biopsies were performed after blood sampling. After making an incision of $2 \mathrm{~cm}$ between the last 2 ribs, liver tissue was extracted using a customized biopsy needle (6-mm o.d.; Weber et al., 2013). The tissue samples were immediately frozen in liquid nitrogen and stored at $-80^{\circ} \mathrm{C}$ until further analyses.

Liver tissue was pulverized using a mortar and pestle under liquid nitrogen. To determine the DM content of the liver, tissue samples $(50 \mathrm{mg}$ ) were dried for 3 $\mathrm{h}$ at $105^{\circ} \mathrm{C}$. Tissue preparation for mRNA quantification was recently described by Weber et al. (2017). Briefly, total RNA was extracted from nitrogen-frozen, homogenized powdered tissue of the liver with TRIzol reagent (Life Technologies, Darmstadt, Germany). Integrity and quality of total RNA were confirmed by gel electrophoresis and by measuring the RNA integrity number value with a bioanalyzer using an Agilent RNA 6000 Nano Kit (Agilent Bioanalyzer 2100, Agilent, Hamburg, Germany). The mean RNA integrity number for liver tissue was $7.06 \pm 0.19$. The quantity and quality of the total RNA were also measured by the optical density via a spectrophotometer (NanoPhotometer; Implen GmbH, Munich, Germany) at 260:280. For cDNA synthesis, $750 \mathrm{ng}$ of RNA was reverse-transcribed with 200 U of RevertAid Reverse Transcriptase (Thermo Fisher Scientific, Schwerte, Germany) and 250 pmol of random hexamer primers (Metabion International AG, Planegg-Steinkirchen, Germany). The cDNA was diluted 1:4 with diethyl pyrocarbonate water, and aliquots were stored at $-80^{\circ} \mathrm{C}$.

Quantification of the relative mRNA abundance of selected genes was conducted as previously described (Saremi et al., 2012b). Emerin (EMD) and RNA polymerase II (POLR2A) served as reference genes. Primer sequences, accession numbers, and PCR conditions for target genes are listed in Supplemental Table S3 (https://doi.org/10.3168/jds.2019-17135). The selected target genes linked to antioxidative status were catalase $(C A T)$, glutathione peroxidase (GPX1), and superoxide dismutase (SOD1). Genes linked to inflammation were tumor necrosis factor $\alpha(T N F)$, IL-1 $\alpha$ and $1 \beta$ (IL1A, $I L 1 B)$, haptoglobin $(H P)$, serum amyloid A (SAA2), fibrinogen $(F G A)$, C-reactive protein $(C R P)$, and paraoxonase (PON1). Genes associated with prostaglandin synthesis were cyclooxygenase 1 and 2 (COX1, COX2). Primer products were verified by sequencing using a BigDye Terminator v1.1 Cycle Sequencing kit and an ABI 3130 Genetic Analyzer (Life Technologies, Carlsbad, CA). Real-time PCR was conducted with the use of a LightCycler (Roche Molecular Biochemicals, Mannheim, Germany), and SYBR Green I was used as a fluorescent dye. Melting curve analysis and agarose gel electrophoresis were both used for verification of PCR products. Quantification cycle values and amplification efficiencies obtained with the use of LinRegPCR version 2013.0 (Ruijter et al., 2013) were imported into qBASE+ version 2.6.1 (Biogazelle, Gent, Belgium) for all subsequent calculations and quality controls. For normalization, the geometric mean of the reference gene abundance was used. Data are presented as the ratio of the copy numbers of the gene of interest to the geometric mean of the reference gene abundance.

\section{Statistical Analysis}

For statistical analysis, performance data corresponding to the respective plasma samples from every 
second supplementation week (wk 2, 4, and 6) and the third week of the washout period (wk 0) were used. Performance data were analyzed by repeated-measures ANOVA using the MIXED procedure of SAS for Windows, release 9.4 (SAS Institute Inc., Cary, NC). The ANOVA model contained treatment (levels: CTRL, EFA, CLA, EFA+CLA), dosage (levels: 0, 1, 2, 3), and the interaction treatment $\times$ dosage as fixed factors. Week in milk served as a covariate. Repeated measures on the same animal (= subject) were taken into account using the REPEATED statement of the MIXED procedure with the repeated variable treatment $\times$ dosage, a compound symmetry type of the block diagonal residual covariance matrix and Satterthwaite's denominator degrees of freedom option $(\mathrm{DDFM}=\mathrm{SAT})$. For repeated-measures ANOVA of relative mRNA expression in liver tissue, the model included only the fixed factor treatment [levels: NO (no supplementation), CTRL, EFA, CLA, EFA+CLA], and week in milk was used as covariate. Repeated measures on the same animal (= subject) were taken into account using the REPEATED statement of the MIXED procedure with the repeated variable treatment, a compound symmetry type of the block diagonal residual covariance matrix and the DDFM = SAT option.

The results are presented as least squares means $(\mathbf{L S M}) \pm$ standard error. Pairwise differences of LSM were tested using the Tukey-Kramer procedure. The SLICE statement of the MIXED procedure was used to perform partitioned analyses of the LSM for 2-way interactions. Differences with $P<0.05$ were considered significant.

\section{RESULTS}

\section{FA Profile in Blood Plasma}

The complete data for FA concentrations in total plasma and the FA composition of total fat in blood plasma are presented in Supplemental Tables S4 and S5 (https: //doi.org/10.3168/jds.2019-17135). Concentrations of ALA in blood plasma and in plasma fat increased in EFA and EFA+CLA in a dosage-dependent manner $(P$ $<0.001)$ and were higher in EFA and EFA+CLA than in CLA and CTRL $(P<0.001$; Figure 1A; Supplemental Table S5). At dosage 3, the plasma ALA concentration was higher $(P<0.001)$ in EFA+CLA than in EFA. Concentrations of EPA in blood plasma and plasma fat increased $(P<0.05)$ in EFA and EFA+CLA, whereas EPA concentration in CTRL and CLA decreased $(P$ $<0.05)$ in plasma fat during the experimental period (Figure 1B; Supplemental Table S5). Concentrations of EPA in blood plasma and plasma fat were higher $(P<$
0.05) in CTRL (not for blood plasma) and CLA than in EFA and EFA+CLA before starting the treatment but were higher $(P<0.05)$ in EFA and EFA+CLA than in CTRL and CLA (not at dosage 2) at dosages 2 and 3. The concentration of DPA increased $(P<0.05)$ in blood plasma and plasma fat of EFA+CLA but decreased $(P$ $<0.05$ ) in plasma fat of CTRL and CLA (Figure 1C; Supplemental Table S5). The treatment differences for DPA in blood plasma were comparable with the effects described for EPA. No dosage or treatment differences were seen for DHA, but concentrations in blood plasma and plasma fat were highest $(P<0.05)$ in CLA at the start of the treatment (Figure 1D; Supplemental Table S5). Concentrations of DPA and DHA were also affected $(P<0.01)$ by week in milk.

The plasma concentration of LA increased by dosage in all groups $(P<0.001)$ except CLA and was higher $(P<0.01)$ in EFA+CLA and CTRL compared with CLA at dosage 3 (Figure 1E). The concentration of LA in plasma fat was lower $(P<0.05)$ at dosage 3 in EFA+CLA than in CTRL and CLA (Supplemental Table S5, https://doi.org/10.3168/jds.2019-17135). The plasma concentration of ARA increased $(P<0.01)$ in CTRL and EFA+CLA and was higher $(P<0.05)$ in CTRL and EFA+CLA than in EFA and CLA at dosage 3 (Figure $1 \mathrm{~F}$ ). The concentration of ARA in plasma fat decreased $(P<0.05)$ in EFA and EFA+CLA and was higher $(P<0.05)$ in EFA+CLA than in CTRL before the start of the treatment; however, it was lower $(P<$ 0.05) in EFA than in CLA at dosage 3 (Supplemental Table S5).

Concentrations of cis-9,trans-11 and trans-10,cis-12 CLA in blood plasma and plasma fat increased $(P<$ 0.001) in CLA and EFA+CLA in a dosage-dependent manner and were higher $(P<0.001)$ in CLA and EFA+CLA than in CTRL and EFA at dosages 2 and 3 (Figure $1 \mathrm{G}$ and H; Supplemental Table S5, https://doi .org/10.3168/jds.2019-17135). In addition, the concentrations of both CLA isomers in plasma fat were higher $(P<0.05)$ at dosage 3 in CLA than in EFA+CLA. Concentrations in blood plasma and plasma fat of both CLA isomers were affected by week in milk $(P<0.05)$.

\section{FA Profile in Milk}

The daily FA yield in milk and the FA composition in milk fat for all analyzed FA are presented in Supplemental Tables S6 and S7 (https://doi.org/10.3168/jds .2019-17135). Daily yield and concentration in milk fat of ALA increased in EFA and EFA+CLA in a dosagedependent manner $(P<0.001$; Figure $2 \mathrm{~A}$; Supplemental Table S6). Daily ALA yield was higher $(P<0.001)$ in EFA and EFA+CLA than in CTRL and CLA from 

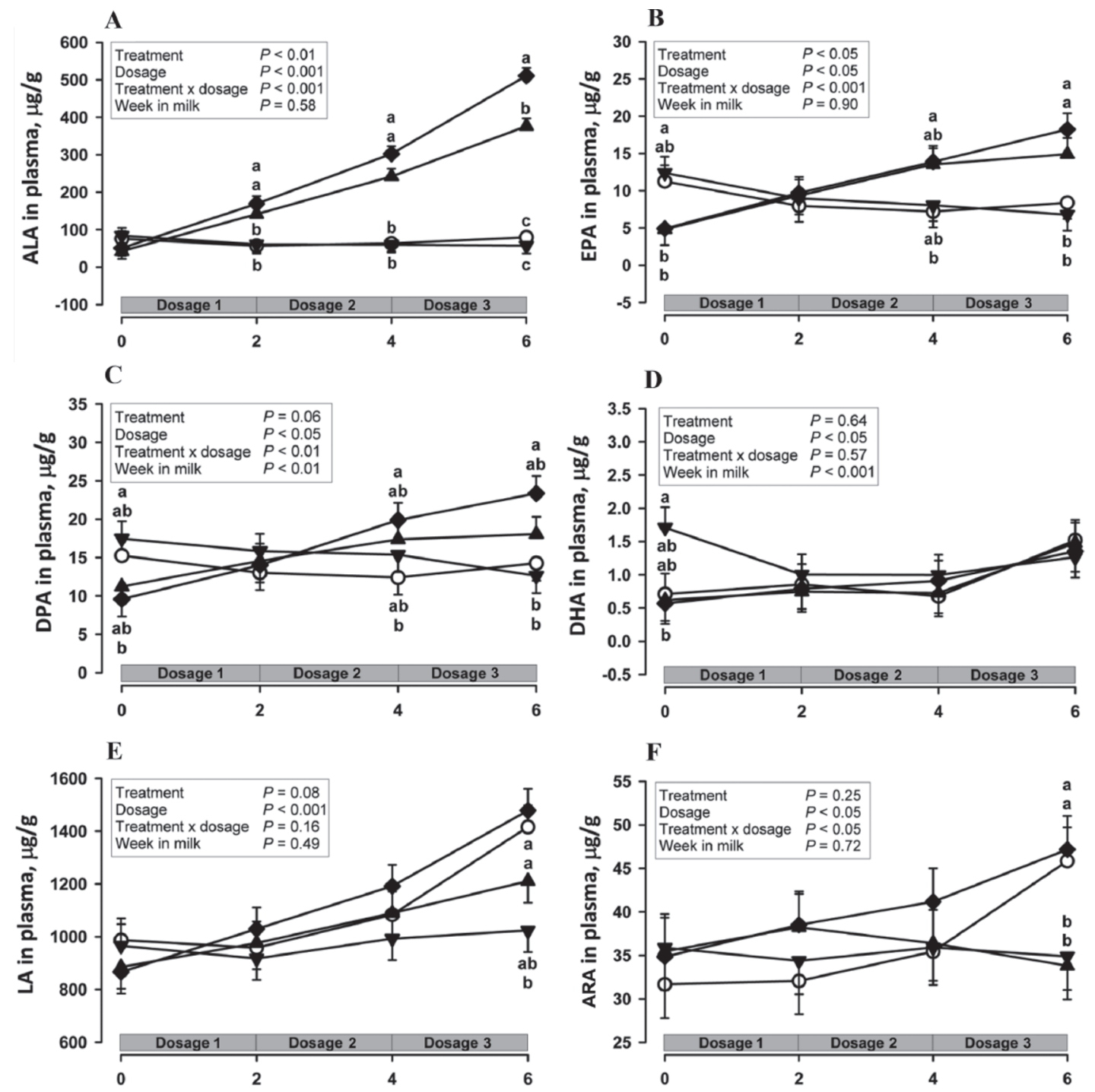

\section{G}

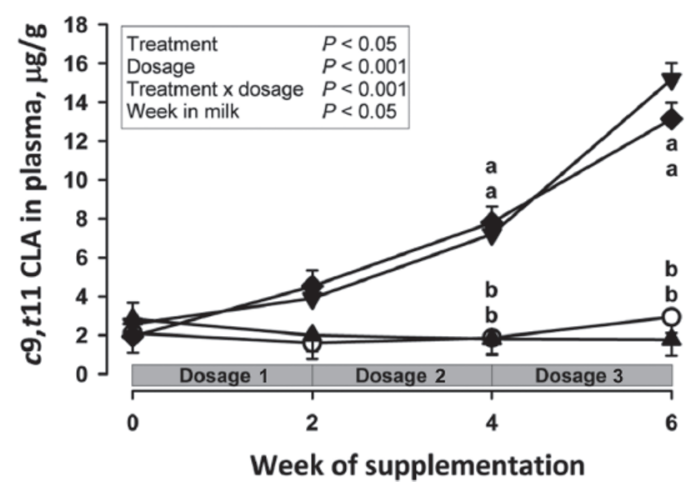

H

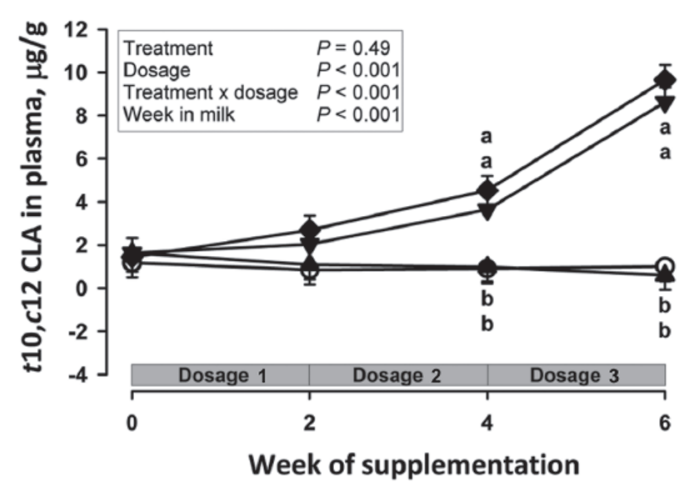

Figure 1. Plasma concentrations of (A) $\alpha$-linolenic acid (ALA), (B) eicosapentaenoic acid (EPA), (C) docosapentaenoic acid (DPA), (D) docosahexaenoic acid (DHA), (E) linoleic acid (LA), (F) arachidonic acid (ARA), (G) cis-9,trans-11 CLA (c9,t11 CLA), and (H) trans-10, cis-12 CLA $(t 10, c 12$ CLA) in cows fed a corn silage-based diet with various treatments at dosages 1,2 , and 3 (wk 2, 4, and 6 , respectively). CTRL (control; O) = coconut oil (Bio-Kokosöl no. 665, Kräuterhaus Sanct Bernhard KG, Bad Ditzenbach, Germany). EFA $(\boldsymbol{\Delta})=$ linseed (Derby Leinöl no. 4026921003087, Derby Spezialfutter GmbH, Münster, Germany) and safflower oil (Gefro Distelöl, Gefro Reformversand Frommlet KG, Memmingen, Germany). CLA ( $\boldsymbol{\nabla})=$ Lutalin (CLA cis-9,trans-11 and trans-10, cis-12, BASF SE, Ludwigshafen, Germany). EFA+CLA ( $\bullet$ = linseed (Derby Leinöl no. 4026921003087), safflower oil (Gefro Distelöl), and Lutalin. Values are LSM \pm SE; n $=4$ per group. Means with different letters $(\mathrm{a}-\mathrm{c})$ differ $(P<0.05)$. 
dosage 2 on and was lower in EFA+CLA than in EFA at dosage $3(P<0.001)$. In milk fat, the ALA concentration was higher $(P<0.05)$ in EFA and EFA+CLA than in CTRL and CLA at dosages 2 and 3 and was higher $(P<0.05)$ in EFA+CLA than in EFA at dosage 3. Milk EPA yield and concentration in fat increased $(P$ $<0.05$ ) with dosage in EFA and EFA+CLA (only in milk fat) and decreased $(P<0.05)$ in CLA (Figure 2B; Supplemental Table S6). The yield and concentration in milk fat of EPA were highest $(P<0.05)$ before the start of the treatment in CLA but were highest $(P<$ $0.05)$ with treatment in EFA and partly higher $(P<$ $0.05)$ in EFA+CLA compared with CTRL regarding the milk fat concentration. Comparable treatment patterns were seen for DPA, resulting in the highest daily yield $(P<0.05)$ in EFA and higher concentration $(P$ $<0.05)$ in milk fat in EFA and EFA+CLA than in CTRL and CLA (Figure 2C; Supplemental Table S6). No DHA was detected in milk.

Daily LA yield in milk was affected by treatment $(P<0.001)$ and dosage $(P<0.01)$ and increased only in EFA in a dosage-dependent manner $(P<0.001$; Supplemental Table S6, https://doi.org/10.3168/jds .2019-17135). The daily yield of LA at dosage 1 was higher $(P<0.05)$ in EFA+CLA than in CLA, at dosage 2 was higher $(P<0.05)$ in EFA than in CTRL and CLA and higher $(P<0.05)$ in EFA+CLA than in CLA, and at dosage 3 was the highest $(P<0.01)$ in EFA and the lowest $(P<0.01)$ in CLA. The concentration of LA in milk fat increased $(P<0.05)$ in EFA, CLA, and EFA+CLA, was lowest $(P<0.05)$ in CTRL (at all dosages), and was highest in EFA+CLA at dosages 2 and 3 (Figure 2D). The concentration of ARA in milk fat was higher $(P<0.05)$ in EFA than in CLA at all dosages (Figure 2E). Daily ARA yield increased $(P<0.05)$ in EFA but decreased $(P<0.05)$ in CLA and EFA+CLA; moreover, it was higher $(P<0.05)$ in CTRL and EFA than in CLA and EFA+CLA (Supplemental Table S6).

The $n-6 / n-3$ ratio in milk fat and in total fat of the blood plasma increased $(P<0.05)$ in CTRL and CLA but decreased $(P<0.05)$ in EFA and EFA+CLA with increasing dosage. In addition, it was greater $(P<$ 0.05) in CTRL and CLA than in EFA and EFA+CLA at each treatment dosage (Supplemental Tables S5 and S7, https://doi.org/10.3168/jds.2019-17135).

The yield and fat concentrations of cis-9,trans-11 and trans-10,cis-12 CLA in milk increased $(P<0.01)$ in a dosage-dependent manner in CLA and EFA+CLA and were higher than those in EFA and CTRL $(P<$ 0.01; Figure 2F and G; Supplemental Table S6, https: //doi.org/10.3168/jds.2019-17135). The sum of FA $<$ C16 in milk fat slightly increased $(P<0.05)$ with dosage in CTRL but decreased $(P<0.001)$ in CLA and
EFA + CLA in a dose-dependent manner (Supplemental Table S7). Daily yield and concentration in milk fat of most of the FA mentioned herein were affected by week in milk $(P<0.001)$.

\section{Animal Performance and Milk Composition}

Dry matter and energy intake were similar between groups, but EB tended to be higher in CLA $(P=0.056)$ compared with other groups and changed with week in milk $(P<0.001$; Table 4; Supplemental Table S8, https://doi.org/10.3168/jds.2019-17135). Body weight and BCS showed no group differences, and BFT was higher in EFA than in CLA $(P<0.05)$ and EFA+CLA $(P<0.001)$ and tended to be higher in EFA than in CTRL $(P=0.06)$ during the whole experimental period regardless of the dosage. Additionally, BFT was affected by week in milk in all groups $(P<0.001)$.

Milk yield showed a treatment effect $(P<0.001)$, was higher in EFA+CLA than in EFA during the complete experimental period $(P<0.05)$, especially at dosage $1(P<0.05)$, and tended to be higher $(P$ $<0.1$ ) in EFA+CLA than in CLA (Table 4). Energycorrected milk was affected by treatment $(P<0.001)$ and decreased $(P<0.05)$ in CLA and EFA+CLA in a dosage-dependent manner (Table 4). Regardless of dosage, ECM was lower $(P<0.05)$ in CLA than in all other groups during the whole experimental period. In addition, ECM was higher $(P<0.01)$ in EFA and CTRL than in CLA at dosages 2 and 3 and was higher $(P<0.01)$ in CTRL than in EFA+CLA at dosage 3 (Table 4). Milk yield and ECM decreased with week in milk $(P<0.001)$ in all groups.

Milk fat content and yield were affected by treatment $(P<0.05)$ and dosage $(P<0.05)$ and decreased $(P<$ $0.001)$ in CLA and EFA+CLA, whereas they increased $(P<0.05)$ in EFA and were highest $(P<0.05)$ at dosage 2 (Table 4$)$. Both parameters were higher $(P<$ 0.001) in EFA and CTRL than in CLA and EFA+CLA (not at dosage 1) at all dosages (Table 4). Milk protein content and yield were affected by treatment $(P<0.05$ and $P<0.001$, respectively; Table 4; Supplemental Table S8, https://doi.org/10.3168/jds.2019-17135). The milk protein content was lower $(P<0.05)$ in CLA and EFA+CLA than in CTRL throughout the entire experimental period. The fat-to-protein ratio was affected by dosage $(P<0.001)$, decreased in CLA and EFA +CLA $(P<0.001)$ in a dosage-dependent manner, and was higher $(P<0.001)$ in CTRL and EFA than in CLA and EFA+CLA at all dosages (Table 4). After the washout period, the fat-to-protein ratio was lower $(P<$ $0.05)$ in EFA than in EFA+CLA. Milk lactose content and yield were both affected by treatment $(P<0.05$ and 
A

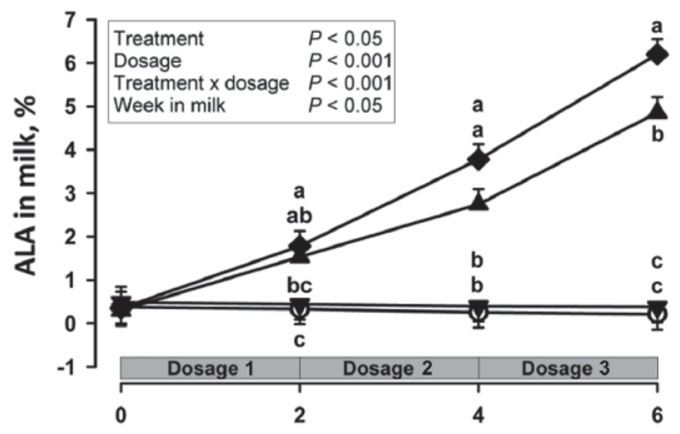

C

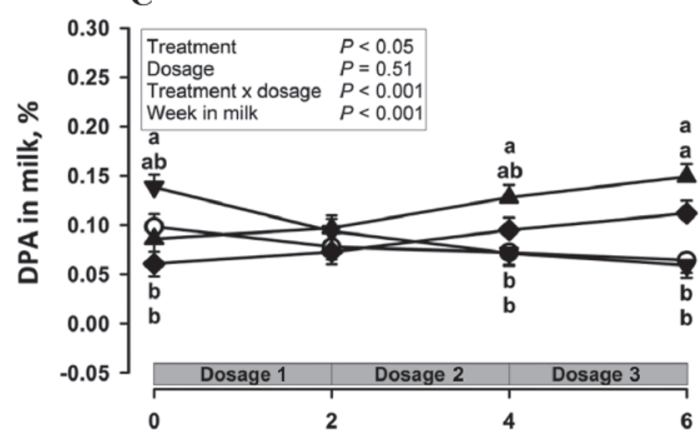

E

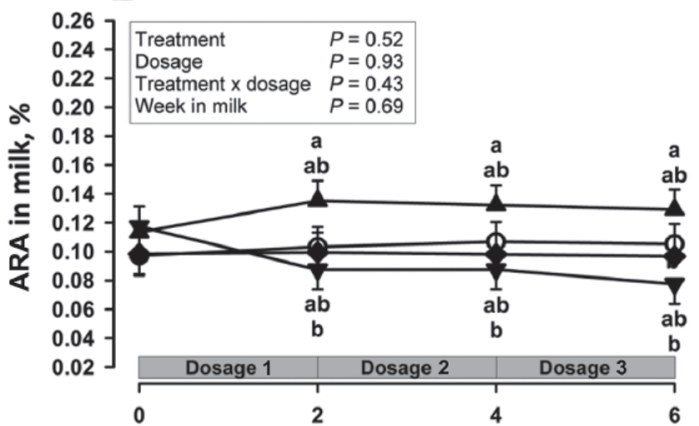

G

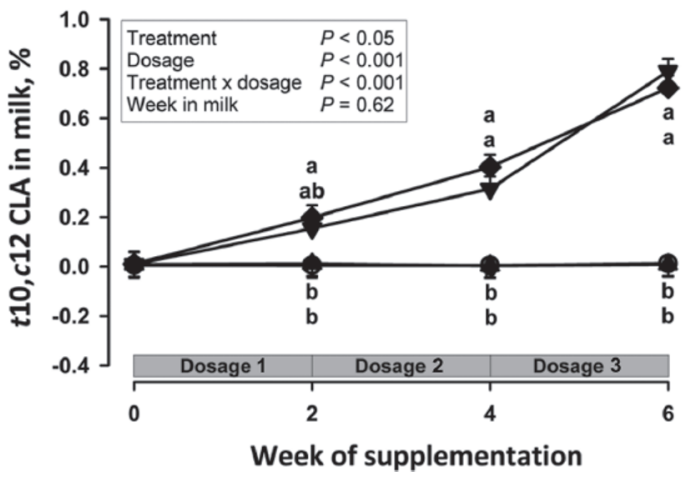

B

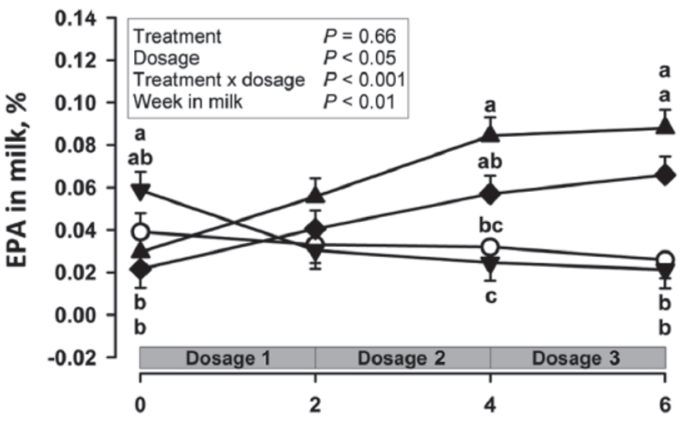

D

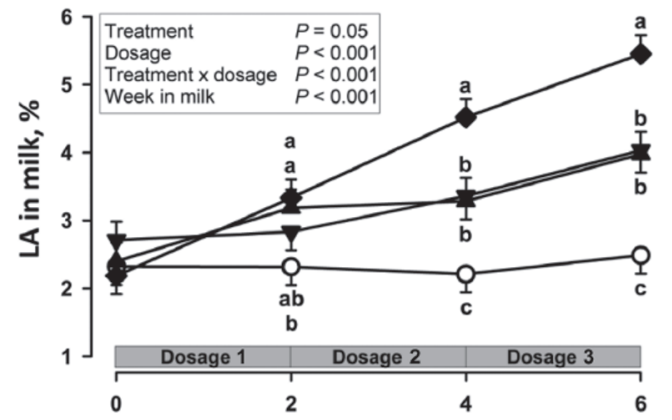

$\mathbf{F}$

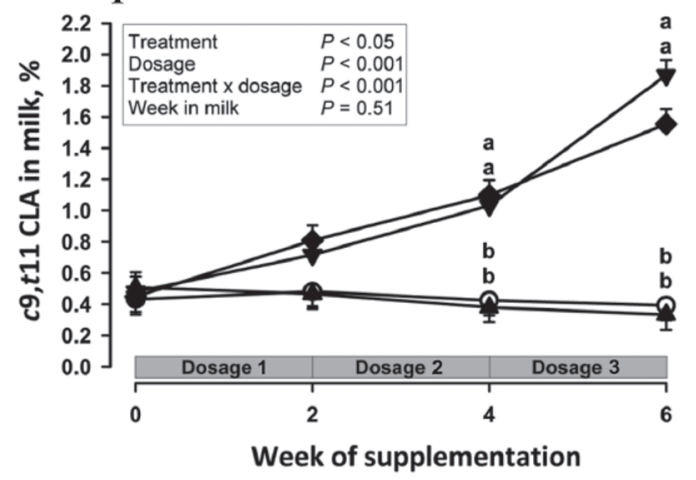

Figure 2. Concentrations of (A) $\alpha$-linolenic acid (ALA), (B) eicosapentaenoic acid (EPA), (C) docosapentaenoic acid (DPA), (D) linoleic acid (LA), (E) arachidonic acid (ARA), (F) cis-9,trans-11 CLA $(c 9, t 11$ CLA), and (G) trans-10, cis-12 CLA (t10,c12 CLA) in milk fat of cows fed a corn silage-based diet with various treatments at dosages 1, 2, and 3 (wk 2, 4, and 6, respectively). CTRL (control; $\bigcirc$ ) $=$ coconut oil (Bio-Kokosöl no. 665. Kräuterhaus Sanct Bernhard KG, Bad Ditzenbach. Germany). EFA (ム) = linseed (Derby Leinöl no. 4026921003087. Derby Spezialfutter GmbH, Münster, Germany) and safflower oil (Gefro Distelöl, Gefro Reformversand Frommlet KG, Memmingen, Germany). CLA $(\boldsymbol{\nabla})=$ Lutalin (CLA cis-9,trans-11 and trans-10, cis-12, BASF SE, Ludwigshafen, Germany). EFA+CLA $(\bullet)=$ linseed (Derby Leinöl no. 4026921003087), safflower oil (Gefro Distelöl), and Lutalin. Values are LSM \pm SE; $\mathrm{n}=4$ per group. Means with different letters $(\mathrm{a}-\mathrm{c})$ differ $(P$ $<0.05)$. 
Table 4. Effects of abomasal treatments on DMI, energy balance, body condition, milk performance, and milk composition ${ }^{1}$

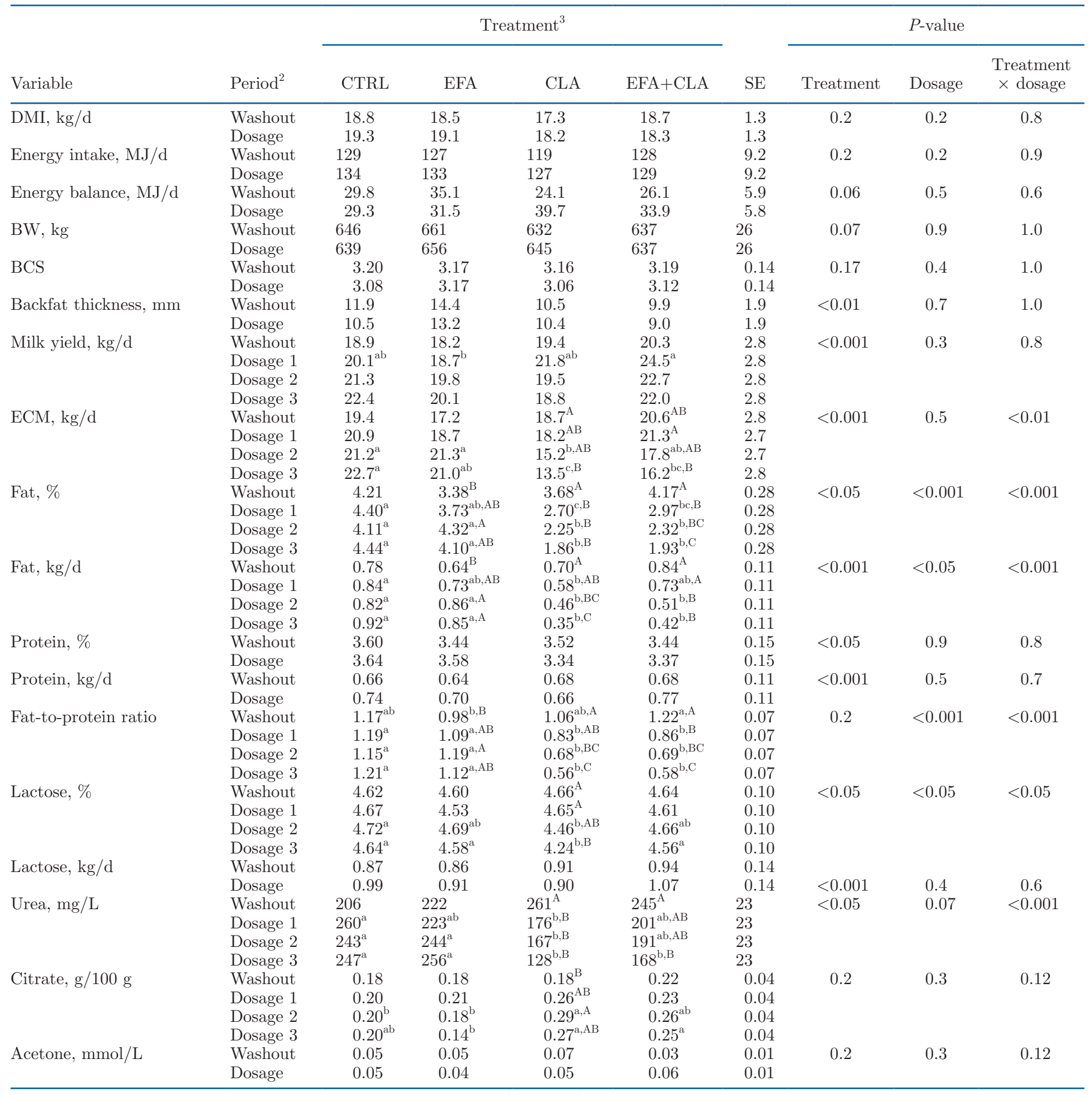

${ }^{\mathrm{a}-\mathrm{c}}$ Means within a row with different lowercase superscripts differ $(P<0.05)$.

${ }^{\mathrm{A}-\mathrm{C}}$ Means within a column with different uppercase superscripts differ $(P<0.05)$.

${ }^{1}$ Values are LSM with SE; $\mathrm{n}=4$ per group.

${ }^{2}$ The initial dosage was doubled twice for 2 wk, resulting in a 6 -wk treatment period with 3 dosages $(1,2,3)$ followed by a 3 -wk washout period. Samples were collected in wk $0,2,4$, and 6 . Means for dosages 1,2, and 3 are given when there was no dosage effect and no treatment effect with an individual dosage. The complete data with respect to dosage for all parameters are presented in Supplemental Table S8 (https://doi . .org/10.3168/jds.2019-17135).

${ }^{3}$ CTRL $($ control) $=$ coconut oil (Bio-Kokosöl no. 665, Kräuterhaus Sanct Bernhard KG, Bad Ditzenbach, Germany). EFA = linseed (Derby Leinöl no. 4026921003087, Derby Spezialfutter GmbH, Münster, Germany) and safflower oil (Gefro Distelöl, Gefro Reformversand Frommlet KG, Memmingen, Germany). CLA = Lutalin (CLA cis-9,trans-11 and trans-10, cis-12, BASF SE, Ludwigshafen, Germany). EFA+CLA = linseed (Derby Leinöl no. 4026921003087), safflower oil (Gefro Distelöl), and Lutalin. 
$P<0.001$, respectively). Milk lactose content decreased $(P<0.001)$ in CLA in a dosage-dependent manner and was lower $(P<0.05)$ in CLA than in CTRL at dosage 2 and lower $(P<0.05)$ than in all other groups at dosage 3 (Table 4). Additionally, there was an effect of week in milk on milk fat yield, protein content and yield, fat-toprotein ratio, and lactose content and yield $(P<0.05)$.

Milk urea concentration was affected by treatment $(P<0.05)$ and decreased $(P<0.05)$ in CLA and EFA+CLA in a dosage-dependent manner; furthermore, it was lower in CLA $(P<0.001)$ and EFA +CLA $(P<0.05)$ than in EFA and CTRL at dosages 2 and 3 (Table 4 ). The milk citrate concentration increased in CLA in a dosage-dependent manner $(P<0.05)$ and was higher in CLA and EFA+CLA than in EFA and CTRL during the entire study $(P<0.05)$, was higher in CLA than in CTRL and EFA at dosage $2(P<$ 0.05), and was higher in CLA and EFA+CLA than in EFA at dosage $3(P<0.05$; Table 4$)$. Concentrations of acetone in milk were not affected by treatment or dosage (Table 4).

\section{VFA in Rumen Fluid}

Ruminal $\mathrm{pH}$ was $7.0 \pm 0.1$ and did not differ among treatments or with dosage. The concentration of total VFA in rumen fluid was $69.3 \pm 10.2 \mathrm{mmol} / \mathrm{L}$; although it changed with week in milk in all groups $(P<0.05)$, it was not affected by treatment. The relative amount of acetic acid was $68.9 \pm 11.9 \mathrm{~mol} \%$, whereas propionic acid was $17.2 \pm 0.7 \mathrm{~mol} \%$ and was affected by week in milk $(P<0.01)$. The ruminal fluid concentration of $n$-butyric acid was $9.6 \pm 1.0 \mathrm{~mol} \%$, and the concentration of isobutyric acid amounted to $1.4 \pm 0.2 \mathrm{~mol}$ $\%$. Ruminal $n$-valeric acid was $1.0 \pm 0.1 \mathrm{~mol} \%$ and changed with week in milk $(P<0.05)$. The concentration of isovaleric acid amounted to $1.7 \pm 0.2 \mathrm{~mol} \%$. The amount of $n$-caproic acid in rumen fluid was $0.3 \pm$ $0.1 \mathrm{~mol} \%$.

\section{Antioxidative Status and Inflammatory Status in Blood Plasma}

The plasma concentration of reactive oxygen metabolites was affected by week in milk $(P<0.01)$. Plasma FRAP tended to increase by dosage in all treatment groups $(P=0.06$; Table 5$)$. Glutathione peroxidase activity in plasma was affected by treatment $(P<$ 0.05), was lower $(P<0.05)$ in CTRL than in EFA considering the whole experimental period (Table 5), and was affected by week in milk $(P<0.001)$. Plasma concentration of tocopherol changed with dosage $(P<$ 0.01 ) but did not differ among groups, whereas plasma concentration of $\beta$-carotene increased $(P<0.05)$ in
EFA and EFA+CLA from washout to dosage 3 and was affected by week in milk $(P<0.001$; Table 5$)$.

\section{Transcript Abundances in Liver Tissue}

The abundance of transcripts measured in this study (Table 6) was not affected by treatment and did not differ among groups. Relative mRNA expression of $I L 1 B$ and $F G A$ was affected by week in milk $(P<0.01$; Table 6).

\section{DISCUSSION}

\section{Effects of FA Supplementation on FA Status in Milk and Blood}

The TMR fed in this study was created to provide low amounts of fat and especially low amounts of EFA. Because the TMR had corn silage and straw as forage sources and corn silage in particular contains high concentrations of LA but low amounts of ALA, the TMR described herein provided particularly low amounts of ALA, which resulted in a low ALA concentration and a high n-6/n-3 FA ratio in milk compared with a mixed grass- and corn silage-based TMR (Weber et al., 2016). The reduction in n-3 FA in milk fat due to feeding a corn silage-based TMR is well known from the literature (Dewhurst et al., 2006; Kliem et al., 2008).

Linseed infusion in EFA and EFA+CLA resulted in a dose-dependent increase in ALA and n-3 FA in blood plasma and milk and fits with data from previous studies (Khas-Erdene et al., 2010; Moallem et al., 2012). A high transfer efficiency of ALA, when administered as linseed oil, was shown in previous studies (Hagemeister et al., 1991; Moallem, 2018). The infusion of low levels of safflower oil in EFA and EFA+CLA cows was intended to provide minor additional amounts of LA and to demonstrate the reduction in the $n-6 / n-3$ ratio in the present study, as a low $\mathrm{n}-6 / \mathrm{n}-3$ FA ratio in milk fat is common in pasture-based feeding systems (Kelly et al., 1998; Dewhurst et al., 2006; Khiaosa-Ard et al., 2015). Therefore, the increase in LA in blood plasma and milk with increasing dosages was less dominant than the increase in ALA in the EFA and EFA+CLA cows, and the n- $6 / \mathrm{n}-3$ ratio in milk fat decreased from 6.9 and $7.1 \pm 0.6$ during washout to 0.9 and $1.0 \pm 0.6$ at dosage 3 in the EFA and EFA+CLA cows, respectively. The greater milk ALA and LA yields in EFA than in EFA+CLA were the consequence of the milk fat-reducing effect of CLA treatment when linseed and safflower oils were infused together with CLA. The lowest milk LA yield was seen in the CLA-supplemented cows. This reduction might be not only a consequence of the CLA milk fat reduction but also an effect of the 
Haubold et al.: ESSENTIAL FATTY ACIDS AND CONJUGATED LINOLEIC ACID IN DAIRY COWS

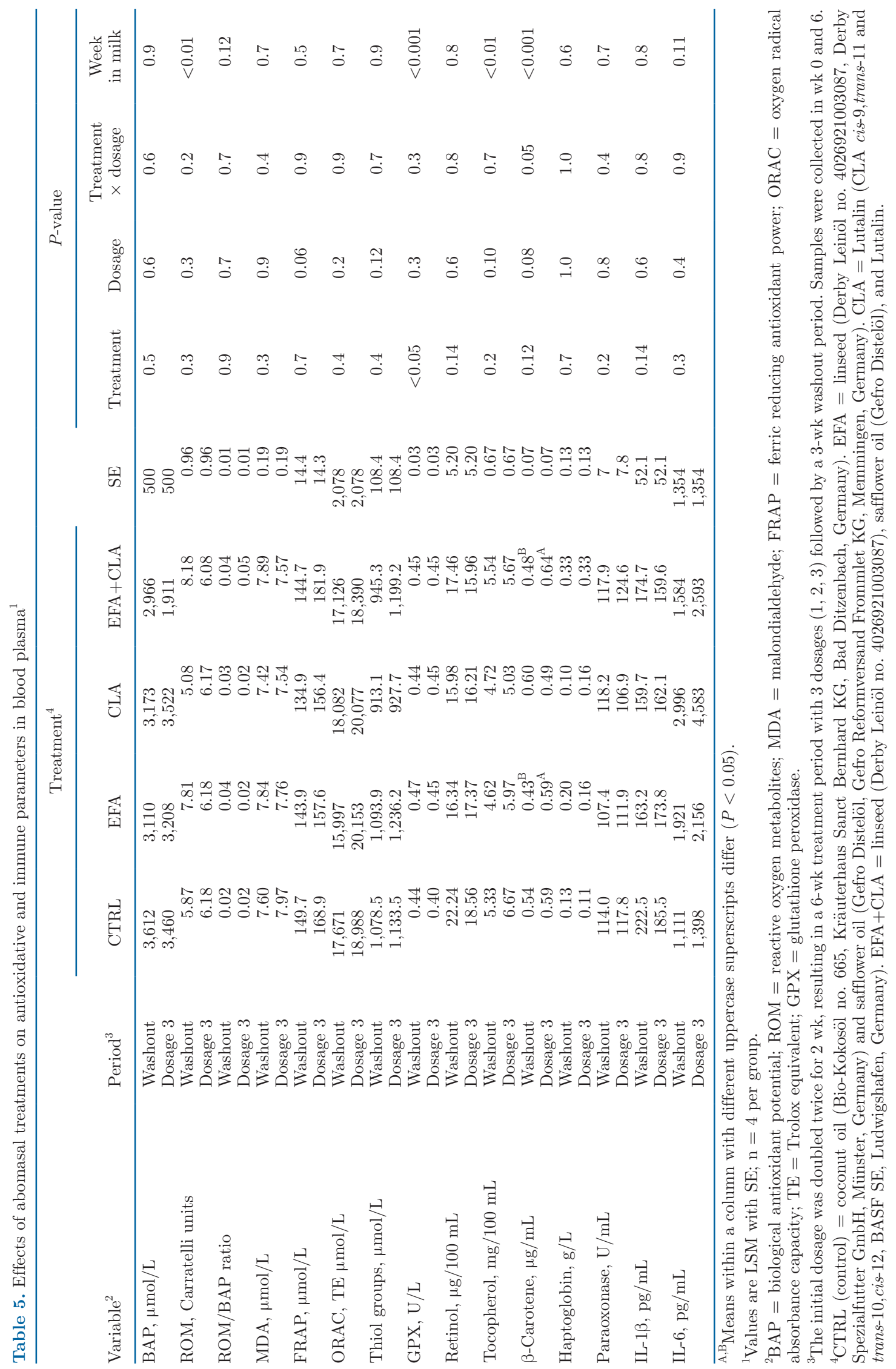


numerically lower DMI of this group compared with the CTRL group. On the other hand, LA increased in the blood plasma of CTRL cows, especially with dosage 3. This increase was associated with the numerical increase in total FA in blood plasma of the CTRL group. However, such an increase in LA was not seen in milk. In contrast, in EFA cows, LA yield was highest in milk but not in blood plasma at dosage 3. Most likely, less LA was transported into the mammary gland in CTRL cows compared with EFA cows.

The EFA and EFA+CLA treatments resulted in increased EPA and DPA blood plasma and milk fat concentrations, indicating support of ALA elongation and desaturation in a dosage-dependent manner in the present study. Daily EPA and DPA yield in milk increased in a dosage-dependent manner for EFA treatment but not for EFA+CLA treatment because of the milk fat reduction due to the CLA treatment. The transformation of ALA into EPA and DPA is especially high when ALA is not degraded in the rumen (Hagemeister et al., 1991), but EPA synthesis was also significant in cows fed linseed (He et al., 2011). The partly elevated concentrations of EPA and DPA in blood plasma and milk at the start of the treatment period in CTRL and
CLA may indicate that the washout period was too short in the present study to bring EPA and DPA back to basal concentrations because the order of treatment was CTRL, EFA, CLA, and EFA+CLA for all cows. The LA supplementation was low in EFA cows, and although LA plasma concentration increased, there was no dose-dependent increase in plasma ARA concentration in EFA cows. However, elevated ARA plasma concentrations were found in cows fed linseed (He et al., 2011). Interestingly, plasma ARA increased in CTRL cows and corresponded to increased LA plasma concentration. In CLA cows, EPA decreased in plasma and milk fat and ARA decreased in milk. This might be a consequence of CLA, especially trans-10, cis-12 CLA, inhibition of FA desaturation in dairy cow (Harvatine and Bauman, 2011). Interestingly, previous investigations indicated an inhibition of ARA synthesis from LA but not an inhibition of EPA from ALA due to trans10, cis-12 CLA treatment (Loor and Herbein, 2003).

Both CLA isomers increased in a dose-dependent manner in milk and blood plasma in CLA and EFA+CLA cows, and CLA supplementation resulted in the abovementioned milk fat reduction (Chouinard et al., 1999; Bauman et al., 2008; Harvatine and Bau-

Table 6. Relative mRNA expression in the liver of dairy cows without or with supplementation ${ }^{1,2}$

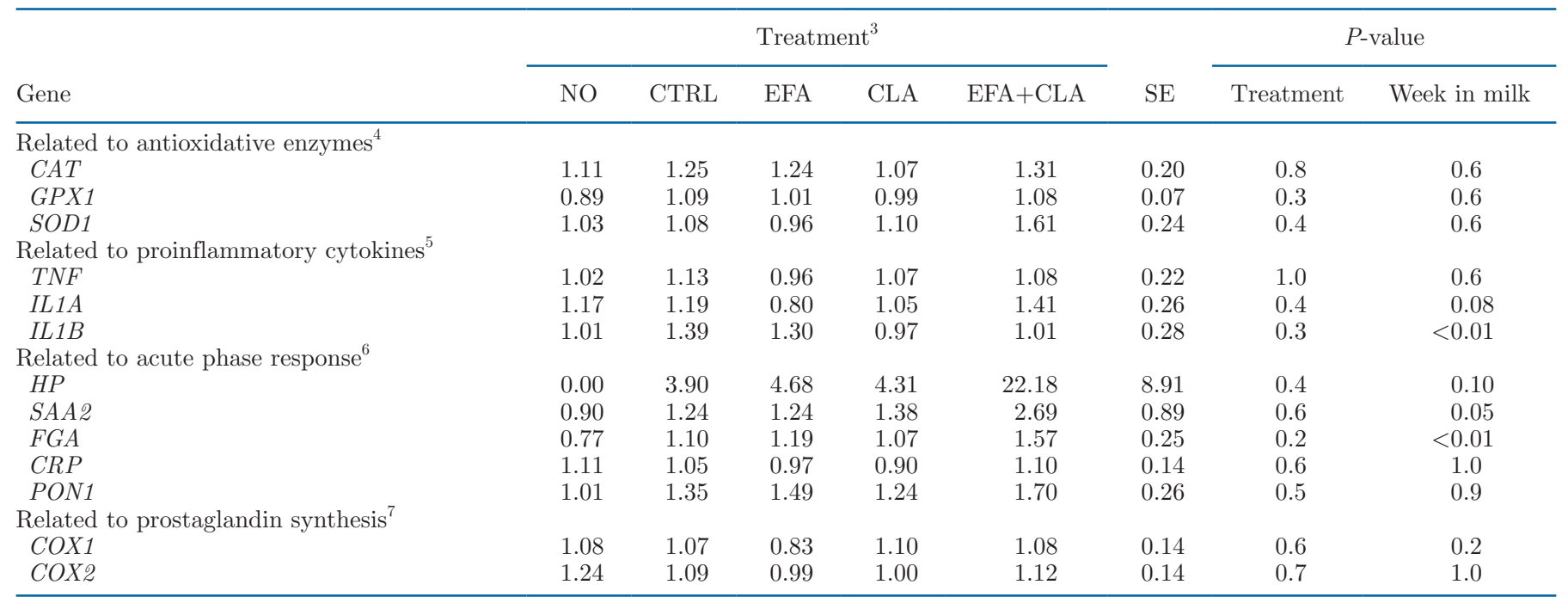

${ }^{1}$ Values are LSM and SE; $\mathrm{n}=4$ per group.

${ }^{2}$ The initial dosage was doubled twice for $2 \mathrm{wk}$, resulting in a 6 -wk treatment period with 3 dosages $(1,2,3)$ followed by a 3 -wk washout period. Samples were collected before the start of the trial (basal sample, no treatment; NO) and after 6 wk of abomasal treatments.

${ }^{3} \mathrm{NO}=$ no supplementation; CTRL (control) = coconut oil (Bio-Kokosöl no. 665, Kräuterhaus Sanct Bernhard KG, Bad Ditzenbach, Germany). EFA = linseed (Derby Leinöl no. 4026921003087, Derby Spezialfutter GmbH, Münster, Germany) and safflower oil (Gefro Distelöl, Gefro Reformversand Frommlet KG, Memmingen, Germany). CLA = Lutalin (CLA cis-9,trans-11 and trans-10, cis-12, BASF SE, Ludwigshafen, Germany). EFA+CLA = linseed (Derby Leinöl no. 4026921003087), safflower oil (Gefro Distelöl), and Lutalin.

${ }^{4} C A T=$ catalase $;$ GPX1 $=$ glutathione peroxidase SOD1 $=$ superoxide dismutase.

${ }^{5} T N F=$ tumor necrosis factor $\alpha ; I L 1 A=$ interleukin- $1 \alpha ; I L 1 B=$ interleukin- $1 \beta$.

${ }^{6} H P=$ haptoglobin; $S A A 2=$ serum amyloid A; FGA = fibrinogen; $C R P=$ C-reactive protein; $P O N 1=$ paraoxonase.

${ }^{7} C O X 1=$ cyclooxygenase $1 ; C O X 2=$ cyclooxygenase 2 . 
man, 2011). The decrease in FA with $<\mathrm{C} 16$ in milk fat of CLA and EFA+CLA indicated the inhibition of milk FA synthesis in cows supplemented with CLA (Bauman et al., 2008, 2011; Harvatine and Bauman, 2011). The inhibition of FA synthesis by CLA may explain differences in FA composition between EFA and EFA+CLA cows; that is, ALA, LA, and PUFA in milk fat were greater in EFA+CLA than in EFA, whereas most of the FA with $<$ C16 in milk fat were greater in EFA than in EFA+CLA. The ALA concentration in blood plasma was greater in EFA+CLA than in EFA, although the infused amounts of linseed and safflower were the same, possibly indicating a greater retention of ALA in blood due to the milk fat-reducing effect of the CLA treatment.

\section{Effects of FA Supplementation on Performance and Milk Production}

There was no acute effect of FA supplementation on DMI or energy intake. In particular, the EFA treatment did not reduce DMI, even at the highest dosage administered in this study. In contrast, previous studies indicated a DMI depression with linseed, either administered via feed and passing the rumen or infused into the abomasum (Leduc et al., 2017; Moallem, 2018). The hypophagic effect known for PUFA probably did not occur in the current study because of the relatively low dosages of linseed oil applied. However, there was a numerical decrease in the DMI with increasing administration of EFA together with CLA. The combined treatment reduced DMI by $2.2 \mathrm{~kg}(13 \%)$ from dosage 1 to dosage 3 in the EFA+CLA cows. The CLA treatment alone did not affect DMI in the present study in a significant manner, but a reduction in DMI by CLA was described in several previous studies (Moallem et al., 2010; von Soosten et al., 2011; Hötger et al., 2013). Therefore, the combination of EFA and CLA treatment might have affected DMI at the highest dosage in a synergistic manner and resulted in a small, although not significant, reduction in DMI.

The EB tended to be highest in CLA-treated cows due to the reduced milk fat release and ECM. The milk-depressing effect of CLA was crucial regarding the changes in the EB during the treatment period. The treatment effect on milk yield was of minor importance in both CLA-treated groups, although the combined treatment of EFA and CLA seems to boost milk yield at the lowest dosage, as this effect was also seen in CLA-treated cows on pasture with high PUFA intake (Mackle et al., 2003). As known from the literature, the effect of CLA on EB is inconsistent, and its milk fatand ECM-reducing effect is often hindered by reduced
DMI or increased milk yield, depending on the lactation stage of the cows (Moallem et al., 2010; von Soosten et al., 2011; Hötger et al., 2013). However, comparison is difficult due to different stages of lactation. Different studies were performed during the transition period, with CLA feeding before or soon after calving or late in the transition phase, whereas cows in the present study were investigated during established to late lactation. The EFA treatment resulted in a small milk fat increase with increasing dosage, as reported previously (Khas-Erdene et al., 2010), but did not affect ECM or EB. The effects of linseed oil treatment on milk production and EB are inconsistent and may depend on the dosage, method of administration, and method of linseed processing (Moallem, 2018). Body weight and $\mathrm{BCS}$ were not affected by treatment, and the treatment effect on BFT is difficult to interpret because BFT in EFA-treated cows was already elevated before the start of the treatment and no dose-dependent relationship was observed.

Milk fat reduction in CLA-treated cows (with or without EFA treatment) was caused by the trans10,cis-12 CLA isomer (Baumgard et al., 2000; Bauman and Griinari, 2003) and in particular was the result of reduced de novo FA synthesis in the mammary gland, as indicated by the dose-dependent decrease in FA $<$ C16 (Baumgard et al., 2002; Mackle et al., 2003; Harvatine and Bauman, 2011). The CLA-inhibiting effect on FA synthesis in the mammary gland was confirmed by the elevated citrate concentration in milk of CLA-treated cows. The citrate-isocitrate pathway is important for generating NADPH for de novo milk FA synthesis and is indirectly associated with FA synthesis in the mammary gland of ruminants; thus, an elevated citrate concentration in milk points at reduced de novo fat synthesis (Faulkner and Peaker, 1982; Garnsworthy et al., 2006; Mellenberger et al., 2009). To our knowledge, this is the first time it has been confirmed that milk fat reduction by CLA results in higher milk citrate levels. Although not different from CTRL, the milk fat content increased during the EFA treatment. An increase in milk fat was previously reported after abomasal or duodenal infusion of linseed, free ALA, or PUFA (mainly oleic and LA) in dairy cows (Benson et al., 2001; Khas-Erdene et al., 2010; Moallem et al., 2012). However, in most studies where linseed was fed as extruded flaxseed, the milk fat content decreased (Moallem, 2018).

Interestingly, milk protein and milk urea concentrations were reduced by CLA treatments. In most previous studies, CLA treatment had no effect or even a stimulating effect on milk protein (Bauman et al., 2008, 2011). However, Moallem et al. (2010) and von 
Soosten et al. (2011) reported reduced milk protein and urea concentrations after CLA treatment during early lactation. Daily milk protein yield partly showed the opposite behavior as milk protein concentration due to a greater milk yield (e.g., in EFA+CLA at dosage 1 ), but although there was an overall treatment effect on milk protein yield, no individual differences were observed. The slight reduction in DMI in CLA and EFA+CLA cows was probably not strong enough to explain the reduced milk urea content. Previous studies have discussed higher body protein accretion and nitrogen retention in cows treated with CLA (Shingfield et al., 2004; von Soosten et al., 2012). Further studies are necessary to clarify the direct effects of CLA on protein synthesis in the mammary gland and on whole-body protein accretion in cows.

Surprisingly, milk lactose concentration decreased dose-dependently in the CLA-treated cows, resulting in a lower lactose milk content in CLA than in all other groups. Such a decrease due to CLA treatment was once described by Bell and Kennelly (2003) using a higher CLA dose than that in the present study, and the decrease was associated with an elevated SCC in milk after CLA treatment. The reduction in lactose content in the present study was mainly the consequence of a reduced lactose content in 1 cow that had elevated SCC in milk during the CLA treatment. However, there was no indication for clinical or subclinical mastitis (the microbial analysis of the milk excluded the presence of pathogens).

\section{Effects of FA Supplementation on Systemic and Hepatic Inflammatory and Antioxidative Status}

The acute phase response is one of the earliest active defense responses of the organism to pathophysiological insult (e.g., infection, injury, and inflammation; Jawor and Tadeusz, 2011). Activated cells respond with the release of key inflammatory cytokines such as tumor necrosis factor $\alpha$, IL-1 3 , and IL- 6 that induce the synthesis of acute phase proteins in the liver such as haptoglobin. The interest in dietary n-3 FA has increased because it was shown that they change inflammatory pathways (e.g., decrease proliferative response of mononuclear cells and prostaglandin synthesis and increase phagocytic capacity and activity of leukocytes; Lessard et al., 2003; Gandra et al., 2016; Sordillo, 2016). In addition, the cis-9,trans-11 CLA isomer in particular has anti-inflammatory capacities (Viladomiu et al., 2016). Studies in bovine mammary gland epithelial cells have indicated reduced gene expression of pro- and anti-inflammatory cytokines after LPS challenge by EFA and CLA (Dipasquale et al., 2018). However, the results of the present study did not indicate any changes in plasma concentrations or changes in hepatic gene expression of inflammatory cytokines or acute phase proteins with respect to EFA and CLA treatment. Neither the CLA nor the EFA+CLA treatment had immediate effects on parameters related to the systemic or hepatic immune response in the cows. Our findings support the results of previous studies demonstrating the failure of CLA treatment to show effects on inflammatory cytokines in dairy cows (Saremi et al., 2012a; Petzold et al., 2015) or bovine peripheral blood mononuclear cells (Renner et al., 2013). The n-3 FA or CLA treatment may influence the inflammatory status and immune response in dairy cows only after an immune challenge (Gandra et al., 2016; Gross et al., 2018). Dairy cows during mid-lactation are not in a proinflammatory state, as this in known from transition cows during early lactation. Therefore, FA treatments in this study revealed no distinct effects on inflammatory parameters in the investigated cows.

As far as blood parameters are concerned, effects of EFA and CLA treatments on the oxidative status in cows were of minor importance in the present study. Only GPX activity was slightly affected by treatment, and plasma FRAP concentrations increased after treatment in all groups. Glutathione peroxidase reduces lipid hydroperoxides and free hydrogen peroxide and is part of the antioxidative system in blood plasma (Bernabucci et al., 2005; Sordillo, 2016). Protective effects of CLA, in particular trans-10, cis-12 CLA, on oxidative damage and stimulation of GPX activity by CLA, in particular cis-9,trans-11 CLA, were shown in mammary epithelial cells in vitro (Basiricò et al., 2015, 2017). Interestingly, as a strong chelating agent, citrate is considered an antioxidant and added in many foods (Silva and Lidon, 2016). The fact that the CLA group had much higher citrate levels in milk compared with the EFA group after dosage 3 shows that CLA provides more antioxidant power to milk than EFA supplementation. The in vitro studies of Basiricò et al. (2017) indicated some minor effects of ALA treatment on the protection against oxidative damage in mammary epithelial cells. However, Basiricò et al. (2017) have discussed the possibility that CLA may be of greater importance for the protection against oxidative damage than ALA and LA in ruminants. The fact that oil treatments were balanced for vitamin E supply may have contributed to the small differences in oxidative status due to the treatment.

The plasma concentration of $\beta$-carotene increased in cows treated with EFA or EFA+CLA. Because there was no such increase in CLA-treated cows, the increase in plasma $\beta$-carotene in particular was the consequence 
of the EFA treatment. $\beta$-Carotene is an important antioxidant that can prevent the formation of ROS (Chew and Park, 2004; Sordillo, 2016), and EFA treatment in the present study may have stabilized the $\beta$-carotene plasma concentration. Higher levels induced by EFA treatment might help improve the radical defense and therefore the antioxidative status in dairy cows. Ashes et al. (1982) observed an increase in $\beta$-carotene concentration after supplementation with protected PUFA and associated this effect with altered properties in high-density lipoproteins, which are involved in $\beta$-carotene transport in plasma. Further investigations on the effect of EFA on $\beta$-carotene metabolism and transport with regard to FA composition in high-density lipoproteins might be of interest. The plasma retinol concentration, on the other hand, was not affected by EFA or CLA treatment. A trend for increased plasma concentration of tocopherol was observed in CTRL and EFA, although vitamin E content was the same in all infused supplements. $\beta$-Carotene may support the antioxidative effect of tocopherol in a synergistic manner (Palozza and Krinsky, 1992). However, CLA treatment in previous studies failed to influence plasma tocopherol concentrations in dairy cows (Sadri et al., 2015; Hanschke et al., 2016) but increased tocopherol concentration in milk (Gessner et al., 2015).

\section{CONCLUSIONS}

Our results confirm that CLA treatment influences EB and affects fat and protein metabolism in dairy cows. The increased citrate content in milk underlines the CLA-induced milk fat reduction in particular by downregulation of de novo FA synthesis in the mammary gland and gives rise to an improved antioxidant status in milk. The systemic or hepatic inflammatory status was less affected by EFA and CLA treatment, and effects on the antioxidative status in mid-lactating dairy cows were of minor importance. A potential reason might be the lack of metabolic and immunological challenges in the cows during the investigated period. Therefore, further studies will investigate the synergistic effects of EFA and CLA treatments on the inflammatory and oxidative status in dairy cows during the transition from late gestation to early lactation.

\section{ACKNOWLEDGMENTS}

We thank Christa Fiedler and Jeannine Gruse [Nutritional Physiology, Leibniz Institute for Farm Animal Biology (FBN), Dummerstorf, Germany] for experimental support and Claudia Reiko (Nutritional Physiology, FBN) for analytical assistance. Additional thanks to the Experimental Animal Facility Cattle of the FBN for excellent technical assistance. The study was supported by BASF (Ludwigshafen, Germany). We further acknowledge the help of the Cattle Breeding Organization of Mecklenburg-West Pomerania (Rinderallianz, Woldegk, Germany) for providing the assortment of cows.

\section{REFERENCES}

Ashes, J. R., R. W. Burley, J. B. Davenport, and G. S. Sidhu. 1982. Effects of dietary supplements of protected lipids on the concentration and transport of beta-carotene and cholesterol in bovine blood and milk: Unusual chromatographic behaviour of the highdensity lipoprotein with high levels of beta-carotene. J. Dairy Res. 49:39-49.

Basiricò, L., P. Morera, D. Dipasquale, A. Troscher, and U. Bernabucci. 2017. Comparison between conjugated linoleic acid and essential fatty acids in preventing oxidative stress in bovine mammary epithelial cells. J. Dairy Sci. 100:2299-2309.

Basiricò, L., P. Morera, D. Dipasquale, A. Troscher, A. Serra, M. Mele, and U. Bernabucci. 2015. Conjugated linoleic acid isomers strongly improve the redox status of bovine mammary epithelial cells (BME-UV1). J. Dairy Sci. 98:7071-7082.

Bauman, D., L. Baumgard, B. Corl, and J. Griinari. 2000. Biosynthesis of conjugated linoleic acid in ruminants. J. Anim. Sci. 77:1-15.

Bauman, D. E., and J. M. Griinari. 2003. Nutritional regulation of milk fat synthesis. Annu. Rev. Nutr. 23:203-227.

Bauman, D. E., K. J. Harvatine, and A. L. Lock. 2011. Nutrigenomics, rumen-derived bioactive fatty acids, and the regulation of milk fat synthesis. Annu. Rev. Nutr. 31:299-319.

Bauman, D. E., J. W. Perfield, K. J. Harvatine, and L. H. Baumgard. 2008. Regulation of fat synthesis by conjugated linoleic acid: Lactation and the ruminant model. J. Nutr. 138:403-409.

Baumgard, L. H., B. A. Corl, D. A. Dwyer, A. Saebo, and D. E. Bauman. 2000. Identification of the conjugated linoleic acid isomer that inhibits milk fat synthesis. Am. J. Physiol. Regul. Integr. Comp. Physiol. 278:R179-R184.

Baumgard, L. H., E. Matitashvili, B. A. Corl, D. A. Dwyer, and D. E. Bauman. 2002. Trans-10,cis-12 conjugated linoleic acid decreases lipogenic rates and expression of genes involved in milk lipid synthesis in dairy cows. J. Dairy Sci. 85:2155-2163.

Bell, J. A., and J. J. Kennelly. 2003. Short communication: Postruminal infusion of conjugated linoleic acids negatively impacts milk synthesis in Holstein cows. J. Dairy Sci. 86:1321-1324.

Benson, J. A., C. K. Reynolds, D. J. Humphries, S. M. Rutter, and D. E. Beever. 2001. Effects of abomasal infusion of long-chain fatty acids on intake, feeding behavior and milk production in dairy cows. J. Dairy Sci. 84:1182-1191.

Benzie, I. F., and J. J. Strain. 1996. The ferric reducing ability of plasma (FRAP) as a measure of "antioxidant power": The FRAP assay. Anal. Biochem. 239:70-76.

Bernabucci, U., B. Ronchi, N. Lacetera, and A. Nardone. 2002. Markers of oxidative status in plasma and erythrocytes of transition dairy cows during hot season. J. Dairy Sci. 85:2173-2179.

Bernabucci, U., B. Ronchi, N. Lacetera, and A. Nardone. 2005. Influence of body condition score on relationships between metabolic status and oxidative stress in periparturient dairy cows. J. Dairy Sci. 88:2017-2026.

Bionaz, M., E. Trevisi, L. Calamari, F. Librandi, A. Ferrari, and G. Bertoni. 2007. Plasma paraoxonase, health, inflammatory conditions, and liver function in transition dairy cows. J. Dairy Sci. 90:1740-1750.

Calder, P. C. 2013. Feeding the immune system. Proc. Nutr. Soc. 72:299-309.

Cao, G., and R. L. Prior. 1999. Measurement of oxygen radical absorbance capacity in biological samples. Methods Enzymol. 299:5062. 
Chew, B. P., and J. S. Park. 2004. Carotenoid action on the immune response. J. Nutr. 134:257S-261S.

Chilliard, Y., A. Ferlay, and M. Doreau. 2001. Effect of different types of forages, animal fat or marine oils in cow's diet on milk fat secretion and composition, especially conjugated linoleic acid (CLA) and polyunsaturated fatty acids. Livest. Prod. Sci. 70:31-48.

Chouinard, P. Y., L. Corneau, D. M. Barbano, L. E. Metzger, and D. E. Bauman. 1999. Conjugated linoleic acids alter milk fatty acid composition and inhibit milk fat secretion in dairy cows. J. Nutr. 129:1579-1584.

Contreras, G. A., S. A. Mattmiller, W. Raphael, J. C. Gandy, and L. M. Sordillo. 2012. Enhanced n-3 phospholipid content reduces inflammatory responses in bovine endothelial cells. J. Dairy Sci. 95:7137-7150.

de Roos, A. P., H. J. van den Bijgaart, J. Horlyk, and G. de Jong. 2007. Screening for subclinical ketosis in dairy cattle by Fourier transform infrared spectrometry. J. Dairy Sci. 90:1761-1766.

Dewhurst, R., K. Shingfield, M. Lee, and N. Scollan. 2006. Increasing the concentrations of beneficial polyunsaturated fatty acids in milk produced by dairy cows in high-forage systems. Anim. Feed Sci. Technol. 131:168-206.

Dipasquale, D., L. Basirico, P. Morera, R. Primi, A. Tröscher, and U. Bernabucci. 2018. Anti-inflammatory effects of conjugated linoleic acid isomers and essential fatty acids in bovine mammary epithelial cells. Animal 12:2108-2114.

Edmonson, A. J., I. J. Lean, L. D. Weaver, T. Farver, and G. Webster. 1989. A body condition scoring chart for Holstein dairy cows. J. Dairy Sci. 72:68-78.

Essid, E., Y. Dernawi, and E. Petzinger. 2012. Apoptosis induction by OTA and TNF-alpha in cultured primary rat hepatocytes and prevention by silibinin. Toxins (Basel) 4:1139-1156.

Faulkner, A., and M. Peaker. 1982. Reviews of the progress of dairy science - Secretion of citrate into milk. J. Dairy Res. 49:159-169.

Ferlay, A., B. Martin, P. Pradel, J. B. Coulon, and Y. Chilliard. 2006 Influence of grass-based diets on milk fatty acid composition and milk lipolytic system in Tarentaise and Montbeliarde cow breeds. J. Dairy Sci. 89:4026-4041.

Ferré, N., J. Camps, E. Prats, E. Vilella, A. Paul, L. Figuera, and J. Joven. 2002. Serum paraoxonase activity: A new additional test for the improved evaluation of chronic liver damage. Clin. Chem. 48:261-268.

Firl, N., H. Kienberger, T. Hauser, and M. Rychlik. 2013. Determination of the fatty acid profile of neutral lipids, free fatty acids and phospholipids in human plasma. Clin. Chem. Lab. Med. 51:799-810.

Firl, N., H. Kienberger, and M. Rychlik. 2014. Validation of the sensitive and accurate quantitation of the fatty acid distribution in bovine milk. Int. Dairy J. 35:139-144.

Gandra, J. R., R. V. Barletta, R. D. Mingoti, L. C. Verdurico, J. E. Freitas Jr., L. J. Oliveira, C. S. Takiya, J. R. Kfoury Jr., M. C. Wiltbank, and F. P. Renno. 2016. Effects of whole flaxseed, raw soybeans, and calcium salts of fatty acids on measures of cellular immune function of transition dairy cows. J. Dairy Sci. 99:45904606.

Garnsworthy, P. C., L. L. Masson, A. L. Lock, and T. T. Mottram. 2006. Variation of milk citrate with stage of lactation and de novo fatty acid synthesis in dairy cows. J. Dairy Sci. 89:1604-1612.

German Society for Fat Science. 2015. DGF-Einheitsmethoden. Vol. 2. C-IV 11 e Fettsäuremethylester (TMSH-Methode). Wissenschaftliche Verlagsgesellschaft, Frankfurt am Main, Germany.

Gessner, D. K., E. Most, G. Schlegel, K. Kupczyk, F. J. Schwarz, and K. Eder. 2015. Concentrations of retinol and tocopherols in the milk of cows supplemented with conjugated linoleic acid. J. Anim. Physiol. Anim. Nutr. (Berl.) 99:1039-1046.

GfE (German Society of Nutrition Physiology). 2001. Empfehlungen zur Energie- und Nährstoffversorgung der Milchkühe und Aufzuchtrinder [Recommended energy and nutrient supply for dairy cows and heifers]. Ausschuss für Bedarfsnormen der Gesellschaft für Ernährungsphysiologie No. 8. DLG Verlag, Frankfurt am Main, Germany.
GfE (German Society of Nutrition Physiology). 2008. New equations for predicting metabolisable energy of grass and maize products for ruminants. Mitteilung des Ausschusses für Bedarfsnormen der Gesellschaft für Ernährungsphysiologie. Proc. Soc. Nutr. Physiol. 17:191-198.

Greco, L. F., J. T. N. Neto, A. Pedrico, R. A. Ferrazza, F. S. Lima, R. S. Bisinotto, N. Martinez, M. Garcia, E. S. Ribeiro, G. C. Gomes, J. H. Shin, M. A. Ballou, W. W. Thatcher, C. R. Staples, and J. E. P. Santos. 2015. Effects of altering the ratio of dietary n- 6 to n-3 fatty acids on performance and inflammatory responses to a lipopolysaccharide challenge in lactating Holstein cows. J. Dairy Sci. 98:602-617.

Gross, J. J., L. Grossen-Rosti, R. Héritier, A. Tröscher, and R. M. Bruckmaier. 2018. Inflammatory and metabolic responses to an intramammary lipopolysaccharide challenge in early lactating cows supplemented with conjugated linoleic acid. J. Anim. Physiol. Anim. Nutr. (Berl.) 102:e838-e848.

Hagemeister, H., D. Precht, M. Franzen, and C. A. Barth. 1991. Alpha-linolenic acid transfer into milk-fat and its elongation by cows. Fett Wiss. Technologie 93:387-391.

Hanschke, N., M. Kankofer, L. Ruda, M. Holtershinken, U. Meyer, J. Frank, S. Dänicke, and J. Rehage. 2016. The effect of conjugated linoleic acid supplements on oxidative and antioxidative status of dairy cows. J. Dairy Sci. 99:8090-8102.

Harvatine, K. J., and D. E. Bauman. 2011. Characterization of the acute lactational response to trans-10,cis-12 conjugated linoleic acid. J. Dairy Sci. 94:6047-6056.

He, M. L., Y. H. Chung, T. A. McAllister, K. A. Beauchemin, P. S. Mir, J. L. Aalhus, and M. E. R. Dugan. 2011. Inclusion of flaxseed in hay- and barley silage diets increases alpha-linolenic acid in cow plasma independent of forage type. Lipids 46:577-585.

Hötger, K., H. M. Hammon, C. Weber, S. Gors, A. Troscher, R. M. Bruckmaier, and C. C. Metges. 2013. Supplementation of conjugated linoleic acid in dairy cows reduces endogenous glucose production during early lactation. J. Dairy Sci. 96:2258-2270.

Jawor, P., and S. Tadeusz. 2011. Acute phase proteins in cattle. Pages 381-408 in Acute Phase Proteins as Early Non-Specific Biomarkers of Human and Veterinary Diseases. F. Veas, ed. Accessed Jun. 14, 2019. https://www.intechopen.com/books/acute -phase-proteins-as-early-non-specific-biomarkers-of-human-and -veterinary-diseases/acute-phase-proteins-in-cattle.

Kelly, M. L., E. S. Kolver, D. E. Bauman, M. E. Van Amburgh, and L. D. Muller. 1998. Effect of intake of pasture on concentrations of conjugated linoleic acid in milk of lactating cows. J. Dairy Sci. 81:1630-1636.

Khan, N. A., P. Yu, M. Ali, J. W. Cone, and W. H. Hendriks. 2015. Nutritive value of maize silage in relation to dairy cow performance and milk quality. J. Sci. Food Agric. 95:238-252.

Khas-Erdene, Q., J. Q. Wang, D. P. Bu, L. Wang, J. K. Drackley, Q. S. Liu, G. Yang, H. Y. Wei, and L. Y. Zhou. 2010. Short communication: Responses to increasing amounts of free alpha-linolenic acid infused into the duodenum of lactating dairy cows. J. Dairy Sci. 93:1677-1684.

Khiaosa-Ard, R., M. Kreuzer, and F. Leiber. 2015. Apparent recovery of C18 polyunsaturated fatty acids from feed in cow milk: A meta-analysis of the importance of dietary fatty acids and feeding regimens in diets without fat supplementation. J. Dairy Sci. 98:6399-6414.

Kliem, K. E., R. Morgan, D. J. Humphries, K. J. Shingfield, and D. I. Givens. 2008. Effect of replacing grass silage with maize silage in the diet on bovine milk fatty acid composition. Animal $2: 1850-1858$.

Lands, B. 2014. Historical perspectives on the impact of n-3 and n-6 nutrients on health. Prog. Lipid Res. 55:17-29.

Leduc, M., M. P. Letourneau-Montminy, R. Gervais, and P. Y. Chouinard. 2017. Effect of dietary flax seed and oil on milk yield, gross composition, and fatty acid profile in dairy cows: A meta-analysis and meta-regression. J. Dairy Sci. 100:8906-8927.

Lessard, M., N. Gagnon, and H. V. Petit. 2003. Immune response of postpartum dairy cows fed flaxseed. J. Dairy Sci. 86:2647-2657. 
Loor, J. J., and J. H. Herbein. 2003. Reduced fatty acid synthesis and desaturation due to exogenous trans10,cis12-CLA in cows fed oleic or linoleic oil. J. Dairy Sci. 86:1354-1369.

Mackle, T. R., J. K. Kay, M. J. Auldist, A. K. H. McGibbon, B. A. Philpott, L. H. Baumgard, and D. E. Bauman. 2003. Effects of abomasal infusion of conjugated linoleic acid on milk fat concentration and yield from pasture-fed dairy cows. J. Dairy Sci. 86:644-652.

Mattos, R., C. R. Staples, and W. W. Thatcher. 2000. Effects of dietary fatty acids on reproduction in ruminants. Rev. Reprod. $5: 38-45$.

Mellenberger, R. W., D. E. Bauman, and D. R. Nelson. 2009. Metabolic adaptations during lactogenesis: Fatty acid and lactose synthesis in cow mammary tissue. J. Mammary Gland Biol. Neoplasia 14:261-268.

Moallem, U. 2018. Invited review: Roles of dietary n-3 fatty acids in performance, milk fat composition, and reproductive and immune systems in dairy cattle. J. Dairy Sci. 101:8641-8661.

Moallem, U., H. Lehrer, M. Zachut, L. Livshitz, and S. Yacoby. 2010. Production performance and pattern of milk fat depression of high-yielding dairy cows supplemented with encapsulated conjugated linoleic acid. Animal 4:641-652.

Moallem, U., D. Vyas, B. B. Teter, P. Delmonte, M. Zachut, and R. A. Erdman. 2012. Transfer rate of alpha-linolenic acid from abomasally infused flaxseed oil into milk fat and the effects on milk fatty acid composition in dairy cows. J. Dairy Sci. 95:5276-5284.

Nagao, K., and T. Yanagita. 2005. Conjugated fatty acids in food and their health benefits. J. Biosci. Bioeng. 100:152-157.

Naumann, C., and R. Bassler. 2012. Die chemische Untersuchung von Futtermitteln. VDLUFA-Verlag, Darmstadt, Germany.

Palmquist, D. L. 2010. Essential fatty acids in ruminant diets. Pages 127-141 in Proc. 21st Annual Ruminant Nutrition Symposium, Gainesville, FL. Institute of Food and Agricultural Sciences, University of Florida, Gainesville, FL.

Palozza, P., and N. I. Krinsky. 1992. $\beta$-Carotene and $\alpha$-tocopherol are synergistic antioxidants. Arch. Biochem. Biophys. 297:184-187.

Pegolo, S., A. Cecchinato, N. Mach, M. Babbucci, M. Pauletto, L. Bargelloni, S. Schiavon, and G. Bittante. 2016. Transcriptomic changes in liver of young bulls caused by diets low in mineral and protein contents and supplemented with n-3 fatty acids and conjugated linoleic acid. PLoS One 11:e0167747.

Petzold, M., U. Meyer, S. Kersten, J. Spilke, G. Breves, and S. Danicke. 2015. Impacts of CLA and dietary concentrate proportion on blood metabolite concentration and proliferation of peripheral blood mononuclear cells of periparturient dairy cows. Animal 9:481-489.

Pires, J. A., J. B. Pescara, A. E. Brickner, R. N. Silva Del, A. P. Cunha, and R. R. Grummer. 2008. Effects of abomasal infusion of linseed oil on responses to glucose and insulin in Holstein cows. J. Dairy Sci. 91:1378-1390.

Reist, M., D. Erdin, D. von Euw, K. Tschuemperlin, H. Leuenberger, C. Delavaud, Y. Chilliard, H. M. Hammon, N. Kuenzi, and J. W. Blum. 2003. Concentrate feeding strategy in lactating dairy cows: Metabolic and endocrine changes with emphasis on leptin. J. Dairy Sci. 86:1690-1706.

Renner, L., S. Kersten, A. Duevel, H. J. Schuberth, and S. Danicke. 2013. Effects of cis-9, trans- 11 and trans-10,cis-12 conjugated linoleic acid, linoleic acid, phytanic acid and the combination of various fatty acids on proliferation and cytokine expression of bovine peripheral blood mononuclear cells. Nutrients 5:2667-2683.

Rezamand, P., B. P. Hatch, K. G. Carnahan, and M. A. McGuire. 2016. Effects of alpha-linolenic acid-enriched diets on gene expression of key inflammatory mediators in immune and milk cells obtained from Holstein dairy cows. J. Dairy Res. 83:20-27.

Ruijter, J. M., M. W. Pfaffl, S. Zhao, A. N. Spiess, G. Boggy, J. Blom, R. G. Rutledge, D. Sisti, A. Lievens, K. De Preter, S. Derveaux, J. Hellemans, and J. Vandesompele. 2013. Evaluation of qPCR curve analysis methods for reliable biomarker discovery: Bias, resolution, precision, and implications. Methods 59:32-46.
Ryan, J. P. 1980. Determination of volatile fatty acids and some related compounds in ovine rumen fluid, urine, and blood plasma, by gas-liquid chromatography. Anal. Biochem. 108:374-384.

Sadri, H., S. Danicke, U. Meyer, J. Rehage, J. Frank, and H. Sauerwein. 2015. Tocopherols and tocotrienols in serum and liver of dairy cows receiving conjugated linoleic acids or a control fat supplement during early lactation. J. Dairy Sci. 98:7034-7043.

Saremi, B., A. Al-Dawood, S. Winand, U. Muller, J. Pappritz, D. von Soosten, J. Rehage, S. Danicke, S. Haussler, M. Mielenz, and H. Sauerwein. 2012a. Bovine haptoglobin as an adipokine: Serum concentrations and tissue expression in dairy cows receiving a conjugated linoleic acids supplement throughout lactation. Vet. Immunol. Immunopathol. 146:201-211.

Saremi, B., H. Sauerwein, S. Danicke, and M. Mielenz. 2012b. Technical note: Identification of reference genes for gene expression studies in different bovine tissues focusing on different fat depots. J. Dairy Sci. 95:3131-3138.

Schröder, U. J., and R. Staufenbiel. 2006. Methods to determine body fat reserves in the dairy cow with special regard to ultrasonographic measurement of backfat thickness. J. Dairy Sci. 89:1-14.

Shingfield, K., D. Beever, C. Reynolds, S. Gulati, D. Humphries, B. Lupoli, G. Hervas, and M. Griinari. 2004. Effect of rumen protected conjugated linoleic acid on energy metabolism of dairy cows during early to mid-lactation. J. Dairy Sci. 87(Suppl. 1):307. (Abstr.)

Shingfield, K. J., L. Bernard, C. Leroux, and Y. Chilliard. 2010. Role of trans fatty acids in the nutritional regulation of mammary lipogenesis in ruminants. Animal 4:1140-1166.

Shokryzadan, P., M. A. Rajion, G. Y. Meng, L. J. Boo, M. Ebrahimi, M. Royan, M. Sahebi, P. Azizi, R. Abiri, and M. F. Jahromi. 2017. Conjugated linoleic acid: A potent fatty acid linked to animal and human health. Crit. Rev. Food Sci. Nutr. 57:2737-2748.

Silva, M. M., and F. C. Lidon. 2016. An overview on applications and side effects of antioxidant food additives. Emir. J. Food Agric. $28: 823-832$.

Silvestre, F. T., T. Carvalho, P. Crawford, J. Santos, C. Staples, T. Jenkins, and W. Thatcher. 2011. Effects of differential supplementation of fatty acids during the peripartum and breeding periods of Holstein cows: II. Neutrophil fatty acids and function, and acute phase proteins. J. Dairy Sci. 94:2285-2301.

Simopoulos, A. P. 2002. The importance of the ratio of omega-6/ omega-3 essential fatty acids. Biomed. Pharmacother. 56:365-379.

Simopoulos, A. P., and J. J. DiNicolantonio. 2016. The importance of a balanced omega- 6 to omega-3 ratio in the prevention and management of obesity. Open Heart 3:e000385.

Skinner, J. G., R. Brown, and L. Roberts. 1991. Bovine haptoglobin response in clinically defined field conditions. Vet. Rec. 128:147-149.

Sordillo, L. M. 2016. Nutritional strategies to optimize dairy cattle immunity. J. Dairy Sci. 99:4967-4982.

Sordillo, L. M., G. A. Contreras, and S. L. Aitken. 2009. Metabolic factors affecting the inflammatory response of periparturient dairy cows. Anim. Health Res. Rev. 10:53-63.

Spector, A. A., and H. Y. Kim. 2015. Discovery of essential fatty acids. J. Lipid Res. 56:11-21.

Spires, H. R., J. H. Clark, R. G. Derrig, and C. L. Davis. 1975. Milk production and nitrogen utilization in response to postruminal infusion of sodium caseinate in lactating cows. J. Nutr. 105:11111121.

Trevisi, E., P. Grossi, F. P. Cappelli, F. S. Cogrossi, and G. Bertoni. 2011. Attenuation of inflammatory response phenomena in periparturient dairy cows by the administration of an $\omega 3$ rumen protected supplement containing vitamin E. Ital. J. Anim. Sci. 10:277-285.

Trevisi, E., N. Jahan, G. Bertoni, A. Ferrari, and A. Minuti. 2015. Pro-inflammatory cytokine profile in dairy cows: Consequences for new lactation. Ital. J. Anim. Sci. 14:3862.

Viladomiu, M., R. Hontecillas, and J. Bassaganya-Riera. 2016. Modulation of inflammation and immunity by dietary conjugated linoleic acid. Eur. J. Pharmacol. 785:87-95. 
von Soosten, D., U. Meyer, M. Piechotta, G. Flachowsky, and S. Danicke. 2012. Effect of conjugated linoleic acid supplementation on body composition, body fat mobilization, protein accretion, and energy utilization in early lactation dairy cows. J. Dairy Sci. 95:1222-1239

von Soosten, D., U. Meyer, E. M. Weber, J. Rehage, G. Flachowsky, and S. Danicke. 2011. Effect of trans-10, cis-12 conjugated linoleic acid on performance, adipose depot weights, and liver weight in early-lactation dairy cows. J. Dairy Sci. 94:2859-2870.

Wathes, D. C., D. R. E. Abayasekara, and R. J. Aitken. 2007. Polyunsaturated fatty acids in male and female reproduction. Biol. Reprod. 77:190-201.

Weber, C., C. Hametner, A. Tuchscherer, B. Losand, E. Kanitz, W. Otten, S. P. Singh, R. M. Bruckmaier, F. Becker, W. Kanitz, and H. M. Hammon. 2013. Variation in fat mobilization during early lactation differently affects feed intake, body condition, and lipid and glucose metabolism in high-yielding dairy cows. J. Dairy Sci. 96:165-180.

Weber, C., C. Schäff, U. Kautzsch, S. Börner, S. Erdmann, R. Bruckmaier, M. Röntgen, B. Kuhla, and H. Hammon. 2017. Variable liver fat concentration as a proxy for body fat mobilization postpartum has minor effects on insulin-induced changes in hepatic gene expression related to energy metabolism in dairy cows. J. Dairy Sci. 100:1507-1520.

Weber, C., A. Tröscher, H. Kienberger, M. Rychlik, and H. M. Hammon. 2016. Performance and fatty acid status in dairy cows fed a diet with reduced essential fatty acid content. Pages 245-246 in Energy and Protein Metabolism and Nutrition. EAAP no. 137. J. Skomial and H. Lapierre, ed. Wageningen Academic, Wageningen, the Netherlands.

Yu, Y., P. H. Correll, and J. P. Vanden Heuvel. 2002. Conjugated linoleic acid decreases production of pro-inflammatory products in macrophages: Evidence for a PPAR gamma-dependent mechanism. Biochim. Biophys. Acta 1581:89-99.

\section{ORCIDS}

A. Tröscher ( $\odot$ https://orcid.org/0000-0002-4198-4427

U. Bernabucci @ https://orcid.org/0000-0002-8126-3042

E. Trevisi (๑) https://orcid.org/0000-0003-1644-1911

H. M. Hammon (๑) https://orcid.org/0000-0001-8698-1257 